\title{
Invasive grass reduces aboveground carbon stocks in shrublands of the Western US
}

\author{
BETHANYA. BRADLEY*, R. A. HOUGHTON†, JOHN F. MUSTARD* \\ and STEVEN P. HAMBURG \\ *Department of Geological Sciences, Brown University, 324 Brook St., Providence, RI 02912, USA, †Woods Hole Research Center, \\ Falmouth, MA 02540, USA, †Center for Environmental Studies, Brown University, Providence, RI 02912, USA
}

\begin{abstract}
Understanding the terrestrial carbon budget, in particular the strength of the terrestrial carbon sink, is important in the context of global climate change. Considerable attention has been given to woody encroachment in the western US and the role it might play as a carbon sink; however, in many parts of the western US the reverse process is also occurring. The conversion of woody shrublands to annual grasslands involves the invasion of non-native cheatgrass (Bromus tectorum) which in turn leads to increased frequency and extent of fires. We compared carbon storage in adjacent plots of invasive grassland and native shrubland. We scaled-up the impact of this ecosystem shift using regional maps of the current invasion and of the risk of future invasion. The expansion of cheatgrass within the Great Basin has released an estimated $8 \pm 3 \mathrm{TgC}$ to the atmosphere, and will likely release another $50 \pm 20 \mathrm{TgC}$ in the coming decades. This ecosystem conversion has changed portions of the western US from a carbon sink to a source, making previous estimates of a western carbon sink almost certainly spurious. The growing importance of invasive species in driving land cover changes may substantially change future estimates of US terrestrial carbon storage.
\end{abstract}

Keywords: Bromus tectorum, carbon budget, cheatgrass, fire, Great Basin, invasive species, land cover change, woody encroachment

Received 23 December 2005 and accepted 1 March 2006

\section{Introduction}

Terrestrial carbon accounting is an important component of predicting long-term climate change. Largescale changes in land cover affecting carbon storage should be included in estimates of current and future carbon flux. A prominent example of large-scale land cover change is conversion of shrubland to non-native cheatgrass (Bromus tectorum) grassland in the western US. Cheatgrass is a non-native annual grass prevalent in the states of Washington, Oregon, Idaho, and vast areas of Nevada and Utah (Mack, 1981). Cheatgrass tends to invade sagebrush (Artemesia spp.) communities, but is also present in pinyon-juniper (Pinus spp., Juniperus spp.) woodland and, more recently, has invaded lower elevation salt desert shrubland (Atriplex spp.) (Young \& Tipton, 1989). Cheatgrass invasion has been linked to land use disturbance (Gelbard \& Belnap, 2003; Bradley

Correspondence: Bethany Bradley, fax +1 401863 3978;

e-mail: bethany_bradley@brown.edu

(C) 2006 The Authors

Journal compilation (C) 2006 Blackwell Publishing Ltd
\& Mustard, 2006), but the invasive species is likely to expand in area even without disturbance effects (Bradley \& Mustard, 2006). Further, the growth of cheatgrass is enhanced by elevated levels of $\mathrm{CO}_{2}$ relative to other native species (Smith et al., 1987, 2000), suggesting that the competitiveness of cheatgrass will continue for the foreseeable future.

The most compelling reason for including cheatgrass invasion in carbon accounting is close association with fire (D'Antonio \& Vitousek, 1992). Whisenant (1990) showed that fire frequency increases 10-fold, to as often as every 5 years, following cheatgrass invasion. Fire frequency increases because cheatgrass creates dense vegetative cover, and thus, higher fuel load, on lands that formerly contained shrub and bunch grasses separated by open soil (Whisenant, 1990). Once this land burns the wind blown seeds of cheatgrass swiftly recolonize the area, creating a cheatgrass monoculture with a total loss of shrub biomass (Young \& Evans, 1978). Even without repeated fires, cheatgrass dominates previously burned areas, preventing shrub regrowth (Billings, 1990). 
Although shrub loss, or 'woody elimination', is prominent in the western US, it has not been considered in the US terrestrial carbon budget (Houghton et al., 1999; Pacala et al., 2001). Instead, the opposite process of shrub gain, or 'woody encroachment', has received considerable attention. Several studies have described the spread of woody plants into grasslands and shrublands (Archer, 1994; Archer et al., 2001; Asner et al., 2003; Wessman et al., 2004), including sagebrush-dominated systems. In the US some of the difference between ground-based and atmospheric-based estimates of carbon flux (Prentice et al., 2001; Houghton, 2003) has been tentatively attributed to woody encroachment (Houghton et al., 1999; Pacala et al., 2001). An upper limit of carbon accumulation across all nonforested, noncultivated land in the western US is $122 \mathrm{TgC} \mathrm{yr}^{-1}$ (Houghton et al., 1999), though this estimate does not include potentially offsetting decreases in soil carbon (Schlesinger \& Pilmanis, 1998; Goodale \& Davidson, 2002; Jackson et al., 2002). Because woody encroachment is the only land cover change currently considered in the western US, this region is thought to be a net carbon sink. However, consideration of the invasion of annuals in the carbon balance of the region may negate the carbon gains associated with woody encroachment while also reducing the potential land area available for encroachment.

Conversion of woody plant communities to annual communities is an important ecological and biogeochemical process due to its broad spatial scale. Using remote sensing to map cheatgrass on a regional scale, Bradley \& Mustard (2005) found that cheatgrass monocultures with dense understories covered a minimum of $20000 \mathrm{~km}^{2}$, or $5 \%$ of the Great Basin in the 1990s. Based on topography and soil properties $150000 \mathrm{~km}^{2}$ of the Great Basin have been estimated to be at high risk of cheatgrass invasion (Suring et al., 2005; Wisdom et al., 2005).

Woody plant community elimination as a result of invasion of annual grasses may affect carbon storage in several ways. First, carbon is lost through the volatilization of carbon stored in shrub biomass during fires. If burned, these woody communities are unlikely to regenerate (Billings, 1990). Second, net carbon exchange (NCE) is lower in invasive grass communities than in native shrubland, reducing carbon accumulation rates (Verburg et al., 2004; Prater et al., 2006). Third, conversion from a woody to annual life form will likely affect patterns of belowground carbon storage. Shallow soils may have increased carbon content as brome density increases (Ogle et al., 2004), while shrub-dominated systems have extensive rooting systems at $1-2 \mathrm{~m}$ depths and may store more carbon in deeper soils (Jobbagy \& Jackson, 2000; Jackson et al., 2002). Additionally, de- creased vegetative cover on burned landscapes may increase topsoil erosion, leading to losses of shallow soil carbon (D'Antonio \& Vitousek, 1992).

In order to estimate the potential regional impact of cheatgrass invasion on carbon stocks, we compare aboveground carbon storage within plots in the sagebrush steppe and salt desert shrub communities with that of adjacent plots in cheatgrass-dominated grasslands. We also examine soil carbon in the adjacent plots to determine whether fire and associated cheatgrass invasion have led to a change in shallow soil carbon. Finally, we scale-up estimates of aboveground carbon stock changes resulting from the invasion of cheatgrass to the regional level using the current extent of cheatgrass (Bradley \& Mustard, 2005) and extent of potential invasion (Suring et al., 2005; Wisdom et al., 2005).

\section{Methods}

Vegetation cover, aboveground biomass, and near-surface soil carbon of native shrublands and cheatgrass monocultures were measured at three sites in north central Nevada in May 2004. Plots representative of plant communities before and after conversion to cheatgrass grassland were sampled using a paired plot design: one plot in a burned grassland dominated by cheatgrass and another in unburned native shrubland. The paired plots were $30 \times 30 \mathrm{~m}^{2}$, located within $500 \mathrm{~m}$ of each other, and at least $100 \mathrm{~m}$ from any burn edges or roads.

The three sites, representative of lands invaded by cheatgrass, were selected on Bureau of Land Management (BLM) lands subjected to grazing pressures typical of those experienced across the Great Basin. Native vegetation at these sites was representative of the range of communities cheatgrass typically invades, from a low-productivity salt desert shrub community to a high-productivity sagebrush community. Finally, the length of time since fire ranged from 3 to 18 years, with two fire events at one site. Fire frequency is high in cheatgrass-dominated areas (Whisenant, 1990), and multiple burns may become the norm for annual grasslands in the future.

The first site, located west of the Rye Patch reservoir $\left(40.57^{\circ} \mathrm{N}, 118.34^{\circ} \mathrm{W}\right)$ at an elevation of $1280 \mathrm{~m}$ and a mean annual precipitation of approximately $190 \mathrm{~mm}$ (based on the Rye Patch Dam gage $13 \mathrm{~km}$ away), contained a dry desert shrub community, composed primarily of shadscale (Atriplex confertifolia) and saltbush (Atriplex spp.) with some cheatgrass under shrub canopies. Interspaces contained no native grasses. The annual grassland (burned in 2001) contained cheatgrass, as well as the non-native annuals Halogeton glomeratus and Russian thistle (Salsola kali). 

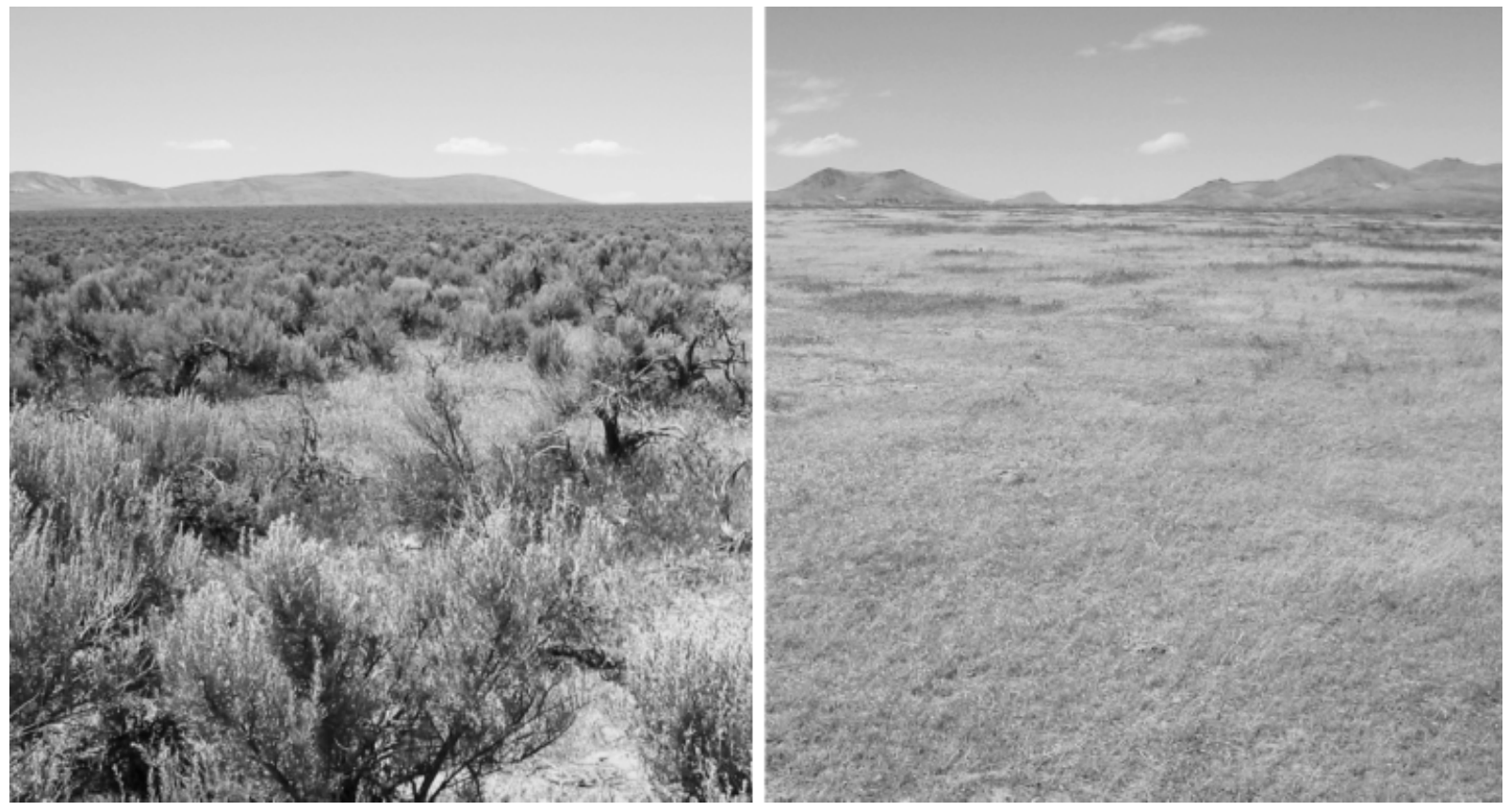

Fig. 1 Sagebrush ecosystem with cheatgrass-dominated interspaces (left) adjacent to cheatgrass grassland (right) at the Jungo site.

The second site, located south of Button Point $\left(41.00^{\circ} \mathrm{N}, 117.58^{\circ} \mathrm{W}\right)$ at an elevation of $1400 \mathrm{~m}$ and a mean annual precipitation of $210 \mathrm{~mm}$ (based on the Winnemucca Airport gage $20 \mathrm{~km}$ away), contained a mixed sagebrush (Artmesia tridentata) and Sandberg blue grass (Poa secunda) community with some cheatgrass under shrub canopies. The annual grassland portion of this site burned in 1986 and was dominated by cheatgrass.

The third site, located north of Jungo $\left(40.99^{\circ} \mathrm{N}\right.$, $117.86^{\circ} \mathrm{W}$ ) at an elevation of $1380 \mathrm{~m}$ and a mean annual precipitation of $210 \mathrm{~mm}$ (based on the Winnemucca Airport gage $13 \mathrm{~km}$ away), contained a sagebrush community with dense cheatgrass in shrub interspaces (Fig. 1). The cheatgrass grassland portion of this site burned twice, once in the mid-1980s and again in 2001.

The Rye Patch, Button Point, and Jungo locations represented the types of shrublands that cheatgrass typically displaces in the Great Basin and thus can be used to estimate aboveground carbon loss associated with the process. We measured aboveground biomass by destructively collecting plant material within ten $0.10 \mathrm{~m}^{2}$ circular subplots within a grid in each plot. The collection was timed to coincide with peak aboveground biomass (mid-May). Litter (dead plant material not attached to a living plant) was minimal at all sites and was not included in the harvested biomass. Harvested plant material was dried at $60^{\circ} \mathrm{C}$ for $48 \mathrm{~h}$ and weighed. Dry biomass was converted to aboveground carbon using a $\mathrm{C} /$ biomass conversion factor of 0.5 .
Percent cover of native and invasive species was measured every meter along six randomly oriented $30 \mathrm{~m}$ line transects within each plot. Cover was classified as soil, native shrub woody vegetation, native shrub green foliage, native perennial grass, or cheatgrass.

The top $10 \mathrm{~cm}$ of soil was collected using a $2 \mathrm{~cm}$ diameter soil corer at 40 locations arrayed systematically in a grid within each plot. Although bulk density is likely to differ among sites, we assumed it to be the same between adjacent plots. Thus, differences in total carbon content correspond to carbon concentration at each site. Soils were dried at $100^{\circ} \mathrm{C}$ for $48 \mathrm{~h}$, sieved to remove rocks $>2 \mathrm{~mm}$ diameter, ground using a mixer mill, and measured for carbon content using a modified Dumas C-N Analyzer. Soil carbon was dominantly organic; inorganic carbon measured within two samples from each plot using inorganic carbon coulometry, accounted for $<1 \%$ of total carbon in all cases.

Average aboveground carbon $\left(\mathrm{gC} \mathrm{m}^{-2}\right)$ was calculated for shrub system of the Great Basin by combining the results of this study with studies reported in the literature to determine average community aboveground carbon. Published studies of aboveground biomass in sagebrush, salt desert shrub, and cheatgrass communities have been collected across the Great Basin (Utah, Idaho, Oregon, and Nevada; Hull \& Pechanec, 1947; Goodman, 1973; Young et al., 1989; Sapsis \& Kauffman, 1991). The difference between average aboveground carbon stored in native shrubland and 
Table 1 Mean percent land cover at three sites in the Great Basin

\begin{tabular}{|c|c|c|c|c|c|}
\hline & Soil & Shrub (woody)* & Shrub (foliage) $)^{\dagger}$ & Native grass & Cheatgrass \\
\hline \multicolumn{6}{|l|}{ Rye Patch } \\
\hline Shrubland & $60(4)$ & $24(3)$ & $11(2)$ & - & $4(2)^{\ddagger}$ \\
\hline Grassland & $54(4)$ & $3(1)^{\S}$ & - & - & $18(3)^{\ddagger}$ \\
\hline \multicolumn{6}{|l|}{ Button Point } \\
\hline Shrubland & $50(3)$ & $18(2)$ & $19(2)$ & $11(2)$ & $2(1)$ \\
\hline Grassland & $34(4)$ & - & - & $9(2)$ & $56(4)$ \\
\hline \multicolumn{6}{|l|}{ Jungo } \\
\hline Shrubland & $28(4)$ & $29(4)$ & $17(3)$ & - & $27(4)$ \\
\hline Grassland & $61(4)$ & - & - & $1(1)$ & $37(4)$ \\
\hline
\end{tabular}

Mean ( \pm standard error).

*Shrub woody nonphotosynthetic vegetation.

†Shrub green foliage cover.

${ }^{\ddagger}$ The invasive annuals Halogeton glomeratus and Russian thistle (Salsola kali) make up the remaining percent cover.

sWoody vegetation at this site consisted of burned stumps.

in cheatgrass monocultures determined the average carbon lost with cheatgrass invasion into salt desert shrub and sagebrush communities. We estimated the potential land cover (precheatgrass) in Great Basin shrublands using estimates of mean annual precipitation from PRISM (Daly et al., 2004) and an average precipitation threshold of $200 \mathrm{~mm}$ to differentiate between salt desert shrub and sagebrush communities (Houghton et al., 1975).

Potential (precheatgrass) land cover distribution in the Great Basin was compared with current cheatgrass extents based on a remote sensing derived map of cheatgrass presence (Bradley \& Mustard, 2005). This map did not include Idaho or central Oregon and classifies $64 \%$ of cheatgrass with a commission error (pixels classified as cheatgrass that contain native vegetation) of 15\% (Bradley \& Mustard, 2005). Thus, regional estimates of current cheatgrass distribution underestimate the total invasion to date. Values of carbon loss per unit area for both salt desert shrub and sagebrush communities were multiplied by the total area currently containing cheatgrass to determine net aboveground carbon loss with current cheatgrass invasion. The same process was repeated using a map of land at high risk of future cheatgrass invasion (Suring et al., 2005; Wisdom et al., 2005) to determine potential future aboveground carbon losses if woody elimination continues.

\section{Results}

All woody cover was completely absent on the annual grassland plots (Table 1). Native grasses were found in only one grassland plot (Button Point, where native grasses were also abundant on the shrubland plot). At the Button Point and Rye Patch sites, shrubland areas contained very low densities of cheatgrass, suggesting that cheatgrass had invaded but was not abundant in the area before burning. At the Jungo site, where dense cheatgrass existed in shrub interspaces in the shrubland plot, shrubs were replaced primarily by bare soil after fire, with only a modest increase in cheatgrass cover.

Aboveground carbon was lower at grassland plots $\left(22-94 \mathrm{~g} \mathrm{C} \mathrm{m}^{2}\right)$ than at shrubland plots $\left(160-670 \mathrm{~g} \mathrm{C} \mathrm{m}^{2}\right)$ due to the loss of woody biomass (Table 2). The values of aboveground carbon for cheatgrass, salt desert ecosystems, and sagebrush systems obtained in these locations were similar to estimates reported from elsewhere in the Great Basin (Hull \& Pechanec, 1947; Goodman, 1973; Young et al., 1989; Sapsis \& Kauffman, 1991).

When our measured values for aboveground biomass in shrub and grassland plots were averaged with results from the literature with the same community types, we estimate that the loss of aboveground carbon averaged $440 \pm 180 \mathrm{~g} \mathrm{C} \mathrm{m}^{-2}$ (SE) when sagebrush systems were lost and $110 \pm 50 \mathrm{~g} \mathrm{C} \mathrm{m}^{-2}$ (SE) when salt desert shrub systems were lost (Table 2). Twenty thousand $\mathrm{km}^{2}$ of the Great Basin are currently dominated by either cheatgrass monoculture or dense cheatgrass in a shrub matrix (Bradley \& Mustard, 2005) (Fig. 2). Although some of these areas have not yet experienced loss of woody vegetation, they are at high risk of fire and future woody elimination. Of the total area, $18000 \mathrm{~km}^{2}$ were formerly sagebrush-dominated communities (average annual rainfall of $>200 \mathrm{~mm}$ ) and $2000 \mathrm{~km}^{2}$ dry desert shrub (average annual rainfall of $<200 \mathrm{~mm}$ ). This pattern of ecosystem conversion has resulted in the loss, or imminent risk of loss once fire occurs, of $8 \pm 3 \mathrm{TgC}$. An additional $150000 \mathrm{~km}^{2}$ in the Great Basin are at high risk of cheatgrass invasion and future woody plant community elimination (Suring et al., 2005; Wisdom et al., 2005) (Fig. 2). Of that area, 
Table 2 Mean aboveground carbon storage $\left(\mathrm{gC} \mathrm{m}^{-2}\right)$ of invaded and native plant communities in the Great Basin

\begin{tabular}{|c|c|c|c|}
\hline & \multirow{2}{*}{$\begin{array}{l}\text { Grassland } \\
\text { Cheatgrass }\end{array}$} & \multicolumn{2}{|l|}{ Shrubland } \\
\hline & & Desert shrub & Sagebrush \\
\hline \multicolumn{4}{|l|}{ This study } \\
\hline Rye Patch & $48(6)^{*}$ & $160(49)^{*}$ & \\
\hline Button Point & $94(26)$ & & 340 (145) \\
\hline Jungo & $22(2)^{*}$ & & $670(290)^{*}$ \\
\hline \multicolumn{4}{|l|}{ Other studies } \\
\hline & $70(5)^{\dagger}$ & $156(32)^{\ddagger}$ & $530(56)^{\S}$ \\
\hline & & $178(32)^{\ddagger}$ & $444(169)^{\top}$ \\
\hline Average & $59(10)$ & $165(38)$ & 497 (165) \\
\hline $\begin{array}{l}\text { Difference from } \\
\text { cheatgrass }\end{array}$ & & $106(48)$ & 438 (175) \\
\hline
\end{tabular}

Mean ( \pm standard error).

*Significant difference between invasive grassland and native shrubland plots $(P<0.05)$.

${ }^{\dagger}$ Idaho - (Hull \& Pechanec, 1947).

ثtah - (Goodman, 1973).

§Oregon - (Sapsis \& Kauffman, 1991).

"Nevada - (Young et al., 1989).

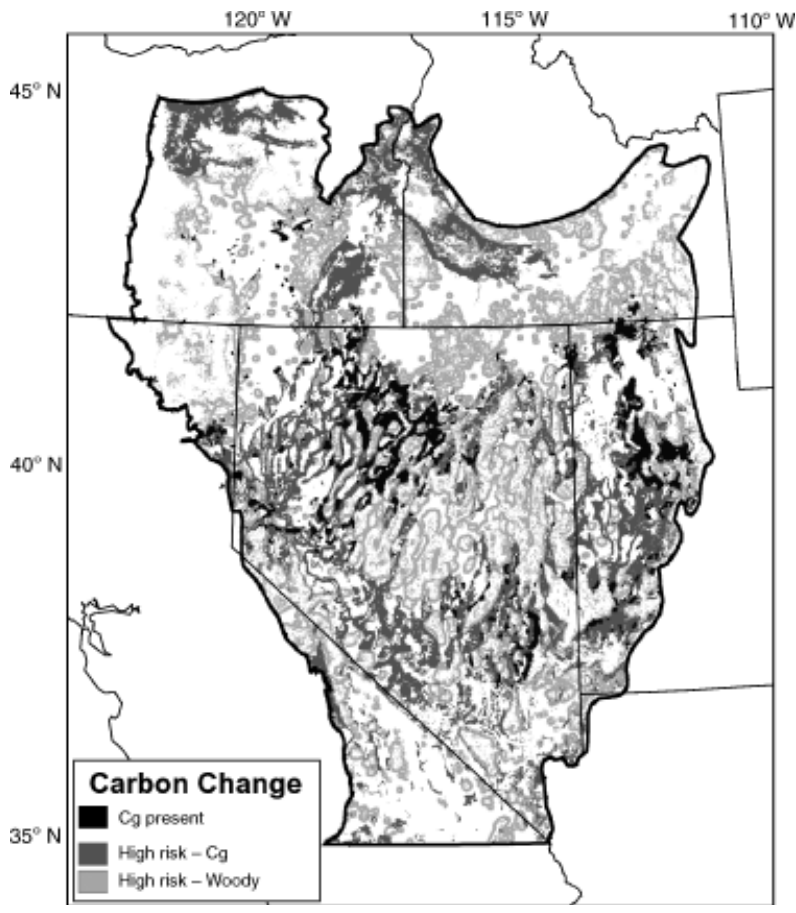

Fig. 2 Western lands contributing to carbon flux. Dark gray areas currently contain cheatgrass. Medium gray areas are at high risk of cheatgrass invasion and are a carbon source. Light gray areas are at high risk of woody encroachment and are a carbon sink.
Table 3 Carbon concentrations in the top $10 \mathrm{~cm}$ of soil on invasive grassland and native shrubland plots in the Great Basin

\begin{tabular}{|c|c|c|c|}
\hline & \multicolumn{3}{|c|}{ Carbon concentration $(\%)$} \\
\hline & \multirow{2}{*}{$\begin{array}{l}\text { Invaded } \\
\text { Cheatgrass }\end{array}$} & \multicolumn{2}{|l|}{ Native } \\
\hline & & $\begin{array}{l}\text { Desert } \\
\text { shrub }\end{array}$ & Sagebrush \\
\hline Rye Patch & $0.48(0.022)$ & \multirow[t]{3}{*}{$0.44(0.013)$} & \\
\hline Button Point & $1.37(0.040)^{*}$ & & $1.03(0.037)^{*}$ \\
\hline Jungo & $0.80(0.034)$ & & $0.85(0.034)$ \\
\hline
\end{tabular}

Mean ( \pm standard error).

*Significant difference between invaded and native plots $(P<0.05)$.

$100000 \mathrm{~km}^{2}$ are currently occupied by sagebrush and $50000 \mathrm{~km}^{2}$ by dry desert shrub. The potential carbon loss in areas at high risk of eventual conversion to annual grassland is $50 \pm 20 \mathrm{TgC}$.

Mean soil carbon concentration in the top $10 \mathrm{~cm}$ was higher in the sagebrush communities than in the desert shrubland, but conversion to cheatgrass had no significant effect on soil carbon concentrations except at Button Point, where the data show a higher carbon concentration within the grassland (Table 3). However, the lack of similar findings at the two other sites and in the literature suggests that this difference may be a result of pre-existing soil differences between the plots. Because the data on soils are inconsistent, we did not include shallow soil carbon values in our estimates of carbon stock change at the regional level.

\section{Discussion}

The difference in percent cover of paired grassland and shrubland plots illustrates the magnitude of the transition from native shrubland to cheatgrass-dominated ecosystems. Woody, nonphotosynthetic vegetation, a critical component of carbon storage in semiarid systems, is completely eliminated. The loss of woody vegetation in these areas is likely permanent, as cheatgrass dominates immediately following fires and competes effectively with native species for resources (Billings, 1990). Cheatgrass dominance in the western US has steadily increased since the early 1900s and is expected to continue its expansion unabated even if not more rapidly (Mack, 1981). Although the process of cheatgrass expansion has long been known, its implications on carbon cycling has been overlooked. This study suggests that the scale of this influence on US carbon budget is large. 
Currently, semiarid lands in the western US are thought to be a net carbon sink as a result of woody encroachment (Houghton et al., 1999; Pacala et al., 2001). However, aboveground carbon losses resulting from the spread of cheatgrass may be of a magnitude sufficient to offset gains resulting from woody encroachment. One of the few studies to have considered woody encroachment over a large area and a long time period found that mesquite expansion over $400 \mathrm{~km}^{2}$ of drylands in northern Texas between 1937 and 1999 accumulated an estimated $120 \mathrm{~g} \mathrm{C} \mathrm{m}^{-2}$ in woody biomass (Asner et al., 2003). The magnitude of this gain is comparable to the loss associated with the conversion of dry desert shrub systems to cheatgrass $\left(110 \mathrm{~g} \mathrm{C} \mathrm{m}^{-2}\right)$ and much less than the loss associated with the conversion of sagebrush systems $\left(440 \mathrm{~g} \mathrm{C} \mathrm{m}^{-2}\right)$.

Cheatgrass invasion not only creates a carbon source, but also reduces the aerial extent of the potential woody sink. Many of the sagebrush systems that cheatgrass is replacing have previously been experiencing woody encroachment via sagebrush crown enclosure or pinyon-juniper expansion (Archer, 1994; Wessman et al., 2004). An upper estimate of all lands potentially susceptible to woody encroachment based on the criteria used by Houghton et al. (1999) (all nonforested, noncultivated land area) encompasses $450000 \mathrm{~km}^{2}$ in the Great Basin. However, pinyon-juniper encroachment is only likely to occur within $5 \mathrm{~km}$ of the sagebrush/ woodland transition (Suring et al., 2005), a total area of only $200000 \mathrm{~km}^{2}$, of which $40000 \mathrm{~km}^{2}$ are highly susceptible to cheatgrass invasion. Thus, a more reasonable estimate for areas with a potential for long-term carbon storage due to woody encroachment could be reduced to $160000 \mathrm{~km}^{2}$, a third of the aerial extent initially considered susceptible to woody encroachment (Fig. 2). If the amount of carbon accumulated over 60 years in north Texas is applied to the maximum area available $\left(160000 \mathrm{~km}^{2}\right)$, the potential accumulation of carbon is $20 \mathrm{TgC}$, less than half of the potential loss of $50 \mathrm{TgC}$ estimated here for the continued spread of cheatgrass. Cheatgrass invasion not only releases carbon, it also eliminates a carbon sink.

Carbon loss values associated with cheatgrass invasion are likely an underestimate. The map of current extents underestimates cheatgrass presence and does not include Idaho and central Oregon. Also, the area estimated to be at high risk of cheatgrass invasion does not include shrublands outside of the Great Basin in Oregon, Washington and eastern Utah (Mack, 1981). In addition to underestimating the extents of woody elimination, we also have not included changes in community NCE (Verburg et al., 2004; Prater et al., 2006).

Prater et al. (2006) compare daily integrated NCE between a sagebrush community and a postfire inva- sive annual community at several time periods in growing seasons between 18 July 2000 and 12 August 2003. Average postfire NCE $\left(0.14 \pm 0.08 \mathrm{SE} \mathrm{g} \mathrm{C} \mathrm{m}^{-2}\right.$ day) is significantly lower than average sagebrush NCE $\left(0.50 \pm 0.12 \mathrm{SE} \mathrm{g} \mathrm{C} \mathrm{m}^{-2}\right.$ day) for the period of measure. Assuming this difference is only present during the summer growing season (1 June-1 August), this difference amounts to a reduced uptake of $22 \pm 12 \mathrm{~g} \mathrm{C} \mathrm{m}^{-2} \mathrm{yr}$ when sagebrush is replaced by invasive annuals. Scaling these values to a regional level would reduce uptake by $0.4 \pm 0.2{\mathrm{TgC} \mathrm{yr}^{-1}}^{-1}$ s sagebrush communities where woody elimination is imminent and by $2.2 \pm 1.2 \mathrm{TgC} \mathrm{yr}^{-1}$ in sagebrush communities at high risk of future conversion to annual grassland.

The effect of woody elimination on belowground carbon storage is highly uncertain. D'Antonio \& Vitousek (1992) suggest that loss of vegetation on burned landscapes may increase soil erosion and lead to a loss of shallow soil carbon. However, our results for the top $10 \mathrm{~cm}$ of soil were inconsistent (Table 3). The higher concentration of soil carbon in cheatgrass communities at the Button Point site combined with the insignificant changes at the other two sites suggest that fire and cheatgrass invasion have not resulted in a loss of shallow soil carbon thus far. Elsewhere, shallow $(30 \mathrm{~cm})$ soil carbon appeared to increase with higher cheatgrass density, although the trend was not significant (Ogle et al., 2004).

However, shallow soils are certainly not the only soil carbon pools affected by woody elimination. Sagebrush rooting depth can reach $2 \mathrm{~m}$ (Taber, 1964), much deeper than annual grasses. Accordingly, studies in other semiarid sites have shown that shrub systems store the same or significantly more soil organic carbon than grasslands (Jackson et al., 2002), particularly between 1 and $2 \mathrm{~m}$ depths (Jobbagy \& Jackson, 2000). The soil carbon dynamics of woody elimination for both shallow and deep soils need further investigation.

The observation that western rangelands may be gaining carbon in some regions and losing it in others lends support to the argument for more complete carbon accounting in computing national annual carbon fluxes (i.e. all areas, all potentially changing components of the ecosystem). Aboveground carbon changes reported here are large relative to total carbon storage in semiarid systems. If large-scale changes have been overlooked in this region, they may have been overlooked in other regions as well.

Including the process of woody elimination in an accounting of carbon stocks in arid and semiarid regions raises a number of questions. Will the increasing importance of non-native grasses reverse the long-term carbon sink associated with woody encroachment? Has it already gone from positive to negative? Is the trend 
limited to the western US or will it affect arid and semiarid carbon stocks at a global scale? Will the rate of grass invasion and associated carbon loss increase in the future? Whatever the answers, it is clear that invasive species in semiarid systems are changing the dynamics of long-term carbon storage. A closer look in other regions seems warranted.

\section{Acknowledgements}

This work was supported by the NASA Land Use Land Cover Change Program, the Global Carbon Cycle Program at NOAA's Climate Program Office, and the American Society for Engineering Education. We thank S. Bradley and L. Schneider for contributions to data collection. O. Sala, W. Schlesinger, and G. Woodwell provided constructive feedback.

\section{References}

Archer S (1994) Woody plant encroachment into southwestern grasslands and savannas: rates, patterns and proximate causes. In: Ecological Implications of Livestock Herbivory in the West (eds Vavra M, Laycock W, Pieper R). pp. 13-68. Society of range management, Denver.

Archer S, Boutton TW, Hibbard KA (2001) Trees in grasslands: biogeochemical consequences of woody plant expansion. In: Global Biogeochemical Cycles in the Climate System (eds Schulze D, Heimann M, Harrison S, Holland E, Lloyd J, Prentice I, Schimel D), pp. 115-138. Academic Press, San Diego.

Asner GP, Archer S, Hughes RF et al. (2003) Net changes in regional woody vegetation cover and carbon storage in Texas Drylands, 1937-1999. Global Change Biology, 9, 316-335.

Billings WD (1990) Bromus tectorum, a biotic cause of ecosystem impoverishment in the Great Basin. In: Patterns and Processes of Biotic Impoverishment (ed. Woodwell GM), pp. 301-322. Cambridge University Press, New York.

Bradley BA, Mustard JF (2005) Identifying land cover variability distinct from land cover change: cheatgrass in the Great Basin Remote Sensing of Environment, 94, 204-213.

Bradley BA, Mustard JF (2006) Characterizing the landscape dynamics of an invasive plant and risk of invasion using remote sensing. Ecological Applications, 16, 1132-1147.

D'Antonio CM, Vitousek PM (1992) Biological invasions by exotic grasses, the grass fire cycle, and global change. Annual Review of Ecology and Systematics, 23, 63-87.

Daly C, Gibson WP, Doggett M, et al. (2004) Up-to-date monthly climate maps for the conterminous United States. In: 14th AMS Conference on Applied Climatology. Paper P5.1, CD-ROM, Seattle, WA.

Gelbard JL, Belnap J (2003) Roads as conduits for exotic plant invasions in a semiarid landscape. Conservation Biology, 17, 420-432.

Goodale CL, Davidson EA (2002) Carbon cycle: uncertain sinks in the shrubs. Nature, 418, 593-594.

Goodman P (1973) Physiological and ecotypic adaptations of plants to salt desert conditions in Utah. Journal of Ecology, 61, 473-494.
Houghton RA (2003) Why are estimates of the terrestrial carbon balance so different? Global Change Biology, 9, 500-509.

Houghton RA, Hackler JL, Lawrence KT (1999) The US carbon budget: contributions from land-use change. Science, 285, 574-578.

Houghton JG, Sakamoto CM, Gifford RO (1975) Nevada's Weather and Climate. Nevada Bureau of Mines and Geology, Reno, NV.

Hull ACJ, Pechanec JF (1947) Cheatgrass - a challenge to range research. Journal of Forestry, 45, 555-564.

Jackson RB, Banner JL, Jobbagy EG et al. (2002) Ecosystem carbon loss with woody plant invasion of grasslands. Nature, 418, 623-626

Jobbagy EG, Jackson RB (2000) The vertical distribution of soil organic carbon and its relation to climate and vegetation. Ecological Applications, 10, 423-436.

Mack RN (1981) Invasions of Bromus tectorum L. into Western North America: an ecological chronicle. Agro-Ecosystems, 7, 145-165.

Ogle SM, Ojima D, Reiners WA (2004) Modeling the impact of exotic annual brome grasses on soil organic carbon storage in a northern mixed-grass prairie. Biological Invasions, 6, 365-377.

Pacala SW, Hurtt GC, Baker D et al. (2001) Consistent land- and atmosphere-based US carbon sink estimates. Science, 292, 2316-2320.

Prater MR, Obrist D, Arnone JA et al. (2006) Net carbon exchange and evapotranspiration in postfire and intact sagebrush communities in the Great Basin. Oecologia, 146, 595-607.

Prentice IC, Farquhar GD, Fasham MJR et al. (2001) The carbon cycle and atmospheric carbon dioxide. In: Climate Change 2001: The Scientific Basis. Contribution of Working Group I to the Third Assessment Report of the Intergovernmental Panel on Climate Change (eds Houghton JT, Ding Y, Griggs DJ, Noguer M, van der Linden PJ, Dai X, Maskell K, Johnson CA), pp. 183-237. Cambridge University Press, Cambridge, UK and New York, NY.

Sapsis DB, Kauffman JB (1991) Fuel consumption and fire behavior associated with prescribed fires in sagebrush ecosystems. Northwest Science, 65, 173-179.

Schlesinger WH, Pilmanis AM (1998) Plant-soil interactions in deserts. Biogeochemistry, 42, 169-187.

Smith SD, Huxman TE, Zitzer SF et al. (2000) Elevated $\mathrm{CO}_{2}$ increases productivity and invasive species success in an arid ecosystem. Nature, 408, 79-82.

Smith SD, Strain BR, Sharkey TD (1987) Effects of $\mathrm{CO}_{2}$ enrichment on four great basin grasses. Functional Ecology, 1, 139-143.

Suring LH, Wisdom MJ, Tausch RJ et al. (2005) Modeling threats to sagebrush and other shrubland communities. In: Habitat Threats in the Sagebrush Ecosystem: Methods of Regional Assessment and Applications in the Great Basin (eds Wisdom MJ, Rowland MM, Suring LH), pp. 114-119. Alliance Communications Group, Allen Press, Lawrence, KS.

Taber RD (1964) The root system of Artemesia tridentata at 9500 feet in Wyoming. Ecology, 45, 633-636.

Verburg PSJ, Arnone JA, Obrist D et al. (2004) Net ecosystem carbon exchange in two experimental grassland ecosystems. Global Change Biology, 10, 498-508.

Wessman CA, Archer S, Johnson LC et al. (2004) Woodland expansion in US Grasslands. In: Land Change Science (ed. 
Gutman G), pp. 185-208 Kluwer Academic Publishers, the Netherlands.

Whisenant SG (1990) Changing fire frequencies on Idaho's snake river plains: ecological and management implications. In: Symposium on Cheatgrass Invasion, Shrub Die-Off, and Other Aspects of Shrub Biology and Management, Las Vegas (eds McArthur ED, Romney EM, Smith SD, Tueller PT), pp. 4-10. Intermountain Research Station, Forest Service, US Department of Agriculture, Ogden, UT.

Wisdom MJ, Rowland MM, Suring LH et al. (2005) Evaluating species of conservation concern at regional scales. In: Habitat Threats in the Sagebrush Ecosystem: Methods of Regional Assessment and Applications in the Great Basin (eds Wisdom MJ,
Rowland MM, Suring LH), pp. 5-74. Alliance Communications Group, Allen Press, Lawrence, KS.

Young JA, Evans RA (1978) Population dynamics after wildfires in Sagebrush Grasslands. Journal of Range Management, 31, 283-289.

Young JA, Evans RA, Palmquist DE (1989) Big sagebrush (Artemesia tridentata) seed production. Weed Science, 37, 47-53.

Young JA, Tipton F (1989) Invasion of cheatgrass into arid environments of the lahontan basin. In: Symposium on Cheatgrass Invasion, Shrub Die-Off, and Other Aspects of Shrub Biology and Management, Las Vegas (eds McArthur ED, Romney EM, Smith SD, Tueller PT), pp. 37-40. Intermountain Research Station, Forest Service, US Department of Agriculture Ogden, UT. 


\section{Science \\ MIAAAS}

Rapid Early Development of Circumarctic Peatlands and Atmospheric $\mathrm{CH} 4$ and $\mathrm{CO} 2$ Variations

Glen M. MacDonald, et al.

Science 314, 285 (2006);

DOI: $10.1126 /$ science. 1131722

\section{The following resources related to this article are available online at www.sciencemag.org (this information is current as of January 30, 2007 ):}

Updated information and services, including high-resolution figures, can be found in the online version of this article at:

http://www.sciencemag.org/cgi/content/full/314/5797/285

Supporting Online Material can be found at: http://www.sciencemag.org/cgi/content/full/314/5797/285/DC1

This article cites 14 articles, 5 of which can be accessed for free:

http://www.sciencemag.org/cgi/content/full/314/5797/285\#otherarticles

This article appears in the following subject collections:

Atmospheric Science

http://www.sciencemag.org/cgi/collection/atmos

Information about obtaining reprints of this article or about obtaining permission to reproduce this article in whole or in part can be found at:

http://www.sciencemag.org/help/about/permissions.dtl 
26. L. G. Rowan, E. L. Hahn, W. B. Mims, Phys. Rev. 137, A61 (1965).

27. Materials and methods are available on Science Online.

28. M. O. Scully, M. S. Zubairy, Quantum Optics (Cambridge Univ. Press, Cambridge, 1997).

29. E. L. Hahn, Phys. Rev. 80, 580 (1950).

30. E. van Oort, M. Glasbeek, Chem. Phys. 143, 131 (1990).

31. C. P. Slichter, Principles of Magnetic Resonance (SpringerVerlag, New York, 1990)
32. We are grateful to ]. Doyle and Doyle lab members for making these experiments possible. We thank A. Mukherjee, N. Khaneja, E. Demler, C. Marcus, and S. Sachdev for many stimulating discussions and experimental help and S. Prawer for providing high-purity diamond samples. This work was supported in part by the NSF Career Award; Army Research Office Multidisciplinary University Research Initiative; and the Packard, Sloan, and Hertz Foundations. F.J. and J.W. acknowledge support from Deutschen Forschungsgemeinschaft (SFB/TR21) and the European Commission (Q.A.P.).
Supporting Online Material

www.sciencemag.org/cgi/content/full/1131871/DC1

Materials and Methods

References

28 June 2006; accepted 23 August 2006

Published online 14 September 2006;

10.1126/science. 1131871

Include this information when citing this paper.

\section{Rapid Early Development of Circumarctic Peatlands and Atmospheric $\mathrm{CH}_{4}$ and $\mathrm{CO}_{2}$ Variations}

\author{
Glen M. MacDonald, ${ }^{1,2 *}$ David W. Beilman, ${ }^{1}$ Konstantine V. Kremenetski, ${ }^{1,3}$ \\ Yongwei Sheng, ${ }^{1}$ Laurence C. Smith, ${ }^{1}$ Andrei A. Velichko ${ }^{3}$
}

An analysis of 1516 radiocarbon dates demonstrates that the development of the current circumarctic peatlands began $\sim 16.5$ thousand years ago $(\mathrm{ka})$ and expanded explosively between 12 and $8 \mathrm{ka}$ in concert with high summer insolation and increasing temperatures. Their rapid development contributed to the sustained peak in $\mathrm{CH}_{4}$ and modest decline of $\mathrm{CO}_{2}$ during the early Holocene and likely contributed to $\mathrm{CH}_{4}$ and $\mathrm{CO}_{2}$ fluctuations during earlier interglacial and interstadial transitions. Given the decreased tempo of peatland initiation in the late Holocene and the transition of many from fens (which generated high levels of $\mathrm{CH}_{4}$ ) to ombrotrophic bogs, a neoglacial expansion of northern peatlands cannot explain the increase in atmospheric $\mathrm{CH}_{4}$ that occurred after 6 ka.

$\mathrm{M}$ odern northern peatlands cover about 4 million $\mathrm{km}^{2}$ across Eurasia and North America and represent the biggest wetland complex in the world (Fig. 1). Today, these peatlands are thought to store 180 to $455 \mathrm{Pg}$ of sequestered carbon while also releasing 20 to $45 \mathrm{Tg}$ per year of $\mathrm{CH}_{4}$ into the atmosphere $(1,2)$. The potential contribution of northern peatlands to fluctuations in atmospheric $\mathrm{CH}_{4}$ and $\mathrm{CO}_{2}$ over the late glacial and Holocene, and during earlier interglacials, has been a matter of much speculation and debate (3-8).

Ice-core records show that $\mathrm{CH}_{4}$ concentrations rose from $\sim 350$ to 650 parts per billion by volume (ppbv) between the last glacial maximum (LGM), which occurred 20 ka $(20,000$ calendar years before C.E. 1950), and the Bølling-Allerød (BA) warm period ( $\sim 15$ to $13 \mathrm{ka})$. They then declined by $\sim 200 \mathrm{ppbv}$ during the Younger Dryas (YD) stadial $(\sim 13$ to $11.5 \mathrm{ka}$ ), rose rapidly to levels over $700 \mathrm{ppbv}$ in the early Holocene (11 to $8 \mathrm{ka}$ ), and then declined again between 8 and $6 \mathrm{ka}$ (3). It has been maintained that because conditions were not favorable for widespread circumarctic peatland formation until after $8 \mathrm{ka}$, tropical wetlands or marine clathrates were the likely sources for the

${ }^{1}$ Department of Geography, ${ }^{2}$ Department of Ecology and Evolutionary Biology, University of California, Los Angeles, CA 90095-1524, USA. ${ }^{3}$ Russian Academy of Sciences, Moscow 109017, Russia.

*To whom correspondence should be addressed. E-mail: macdonal@geog.ucla.edu
$\mathrm{CH}_{4}$ peak that occurred 11 to $8 \mathrm{ka}(4,9)$. On the basis of the assumed late-Holocene development, it has been suggested that northern peatlands played little role in the declining atmospheric $\mathrm{CO}_{2}$, which has also been observed during the period from 11 to $8 \mathrm{ka}(5)$. Others argue that the development of the northern peatland complex contributed substantially to the early-Holocene $\mathrm{CH}_{4}$ increase and simultaneously decreased atmospheric $\mathrm{CO}_{2}$ through carbon sequestration in northern soils $(6-8)$.

Resolving the debate on the potential role of the northern peatlands in early postglacial $\mathrm{CH}_{4}$ variations has become critical since the recent analysis of the deuterium and carbon isotopic composition of $\mathrm{CH}_{4}\left(\delta \mathrm{D}_{\mathrm{CH}_{4}}\right.$ and $\left.\delta^{13} \mathrm{C}_{\mathrm{CH}_{4}}\right)$ from Greenland ice samples, which suggested that the destabilization of marine clathrates is an unlikely explanation for the BA or earlyHolocene $\mathrm{CH}_{4}$ increases $(10,11)$. In view of this evidence, it has been argued that the sustained high levels of $\mathrm{CH}_{4}$ that developed at the close of the YD in part require a persistent terrestrial source linked to the warming climate at that time (11).

Holocene concentrations of atmospheric $\mathrm{CH}_{4}$ reached a minimum of $<600 \mathrm{ppbv}$ at $6 \mathrm{ka}$ and then increased again over the late Holocene to values of about 695 ppbv just before the industrial revolution (3). This late-Holocene increase has been variously attributed either to expansion of northern wetlands due to neoglacial climatic cooling after the Holocene thermal maximum (4) or to the product of ex- panding anthropogenic activity (particularly the expansion of rice- and cattle-based agrarian societies) in the mid- to late Holocene (12). However, recently collected $\mathrm{CH}_{4}$ data from Antarctic ice cores reveal that the mid- to lateHolocene increase is not unique. A similar lateinterglacial increase in Pleistocene atmospheric $\mathrm{CH}_{4}$ occurred $\sim 400 \mathrm{ka}$ during Marine Isotope Stage 11 (MIS11), which clearly cannot reflect anthropogenic sources and has been ascribed instead to natural factors, including expansion of northern wetlands (13).

To address the hypothesis that northern peatland development could have contributed to the late-Pleistocene and Holocene variations in atmospheric $\mathrm{CH}_{4}$ and $\mathrm{CO}_{2}$ outlined above, we collated 1516 basal radiocarbon dates for peat initiation from wetlands throughout highlatitude Europe, Asia, and North America from a wide variety of sources (14). Some areas, such as Fennoscandia, have numerous basal dates for a small geographic area, whereas other very large areas such as central and eastern Siberia have a limited number of dates (Fig. 1). Therefore, we analyzed the compiled data set by raw number of initiation dates, and we also divided the Northern Hemisphere into grids of $2^{\circ}$ latitude by $2^{\circ}$ longitude and assigned a value for peatland initiation based on the oldest basal radiocarbon date in each cell (Fig. 1).

The lack of basal dates older than about $16.5 \mathrm{ka}$ suggests that there was no extensive peatland complex in the northern circumpolar region during the LGM (Fig. 2). This finding is corroborated by palynological data that indicate a paucity of Sphagnum (peat moss) spores from deposits of this age (15). Before $16.5 \mathrm{ka}$, much of the North American and European arctic and subarctic were still covered in ice, and it is likely that the large ice-free areas of Siberia and Beringia were too cold and dry (16) to promote extensive peatland development. This absence of any significant northern peatland complex during the LGM is consistent with the depressed $\mathrm{CH}_{4}$ levels and the relatively low proportion of northern $\mathrm{CH}_{4}$ sources observed in ice-core records (Fig. 3).

In concert with increasing summer insolation and northern high-latitude temperatures, the current northern peatland complex began developing in ice-free portions of North America and Asia between 16.5 and $14 \mathrm{ka}$ and initiating widely on all three northern continents after 14 ka (Figs. 1 and 2). These results dispel the earlier assertion that peatland development in 

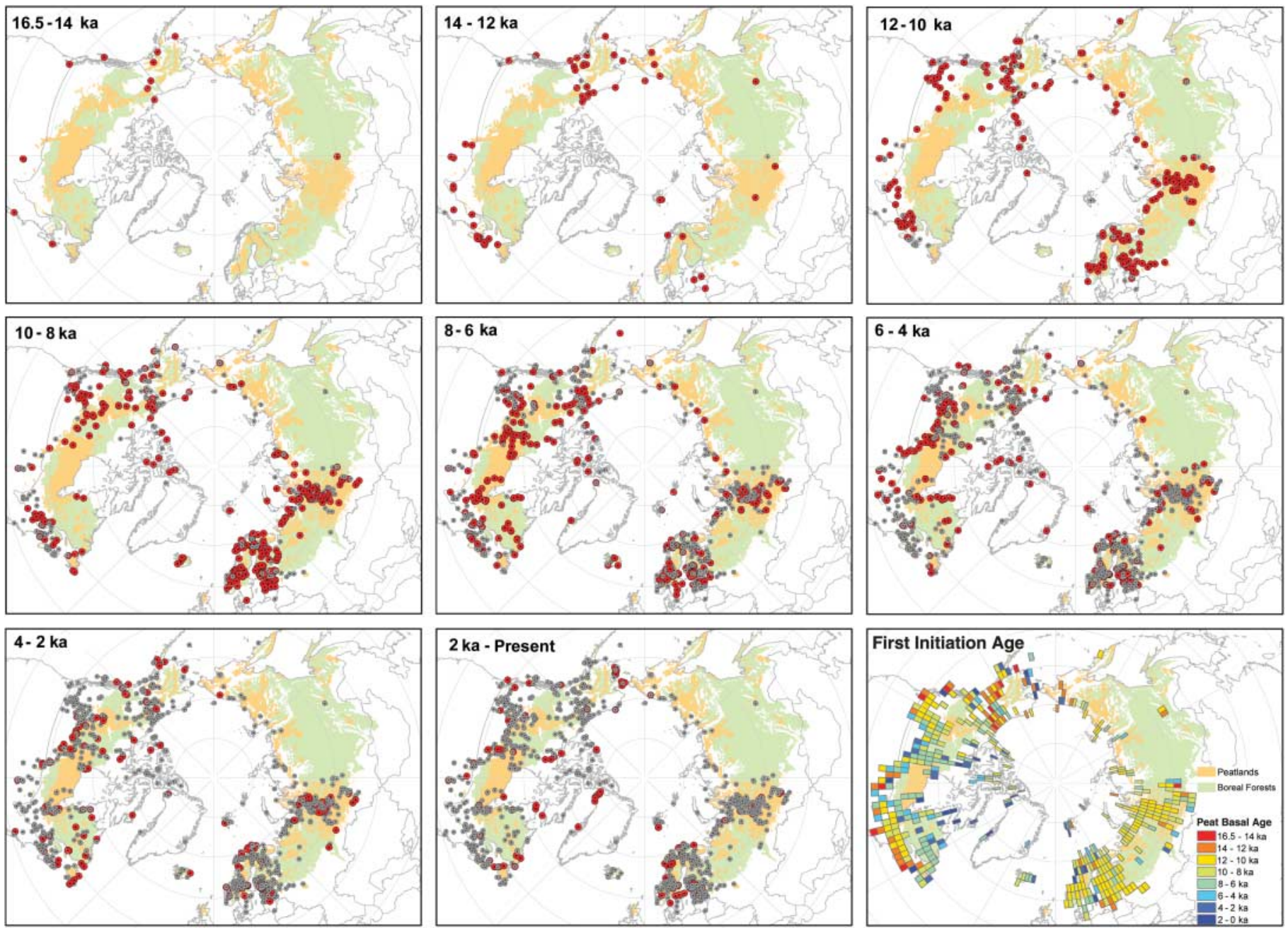

Fig. 1. Map of the current distribution of the northern circumarctic peatland complex and the boreal forest biome developed from a number of sources (SOM text) and the initiation dates of the peatlands based on radiocarbon dates from the base of peat deposits (14). The red dots indicate new peatlands

that initiated during each time slice and the gray dots indicate preexisting peatlands initiated during earlier time slices. The timing of peatland initiation based on $2^{\circ}$ by $2^{\circ}$ grids is shown in the right panel in the bottom row. The grids map the oldest basal peat dates within each grid cell. western Siberia was in advance of development in North America or elsewhere (7). The initial expansion coincides with warming during the BA period (Fig. 3), and it is likely that increasing warmth and moisture and decreasing glacial ice cover promoted peatland growth. Resultant development of the northern peatland complex corresponds with increasing atmospheric $\mathrm{CH}_{4}$ concentrations observed during the BA (Fig. 3). However, the still-limited extent of northern peatlands at this early interval is consistent with evidence for a relatively restricted role of northern wetlands in producing the $\mathrm{BA} \mathrm{CH}_{4}$ increase (Fig. 3). There is a small decline in the rate of new peatland formation during the YD, which may be attributed to the development of cold conditions over much of the Northern Hemisphere and readvances of ice. At the same time, there is a precipitous drop in $\mathrm{CH}_{4}$ recorded in the ice cores (Fig. 3) that seems to reflect additional factors. During the BA and YD periods, it is unlikely that the extent and growth of the northern peatlands was

Fig. 2. Timing of circumarctic peatland establishment in North America (black), Europe (red), and Asia (blue) based on the total number of initiation dates from each region. The occurrence frequency of basal peat radiocarbon ages is plotted as the number of calibrated age

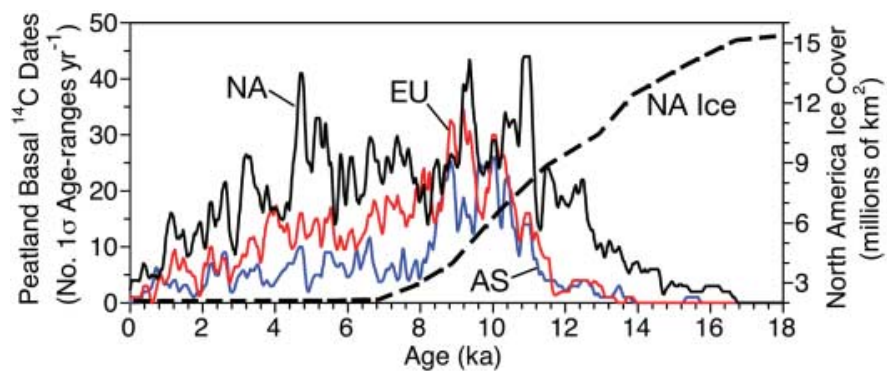

ranges that fall in any year (14), smoothed with a 100-year running mean. The decreasing area of the Laurentide Ice Sheet (dashed line) as it retreated over the late glacial and Holocene (17) is also plotted.

great enough to have significantly affected atmospheric $\mathrm{CO}_{2}$ concentrations.

The initiation of the early Holocene warming at $11.5 \mathrm{ka}$ after the YD is marked by rapid expansion of peatlands throughout the north. The North American peatlands expanded rapidly during this time (Figs. 1 and 2), even though still constrained by the ice extent of the Laurentide
Ice Sheet (17). The tempo of subsequent northern peatland development in North America was influenced by the rate of continued ice retreat and the exposure of land surfaces (Fig. 2). Large areas of northern Asia never supported ice during the LGM (18), and by $11 \mathrm{ka}$, high-latitude climate had warmed (Fig. 3). What remained of the Scandinavian Ice Sheet was restricted to cen- 


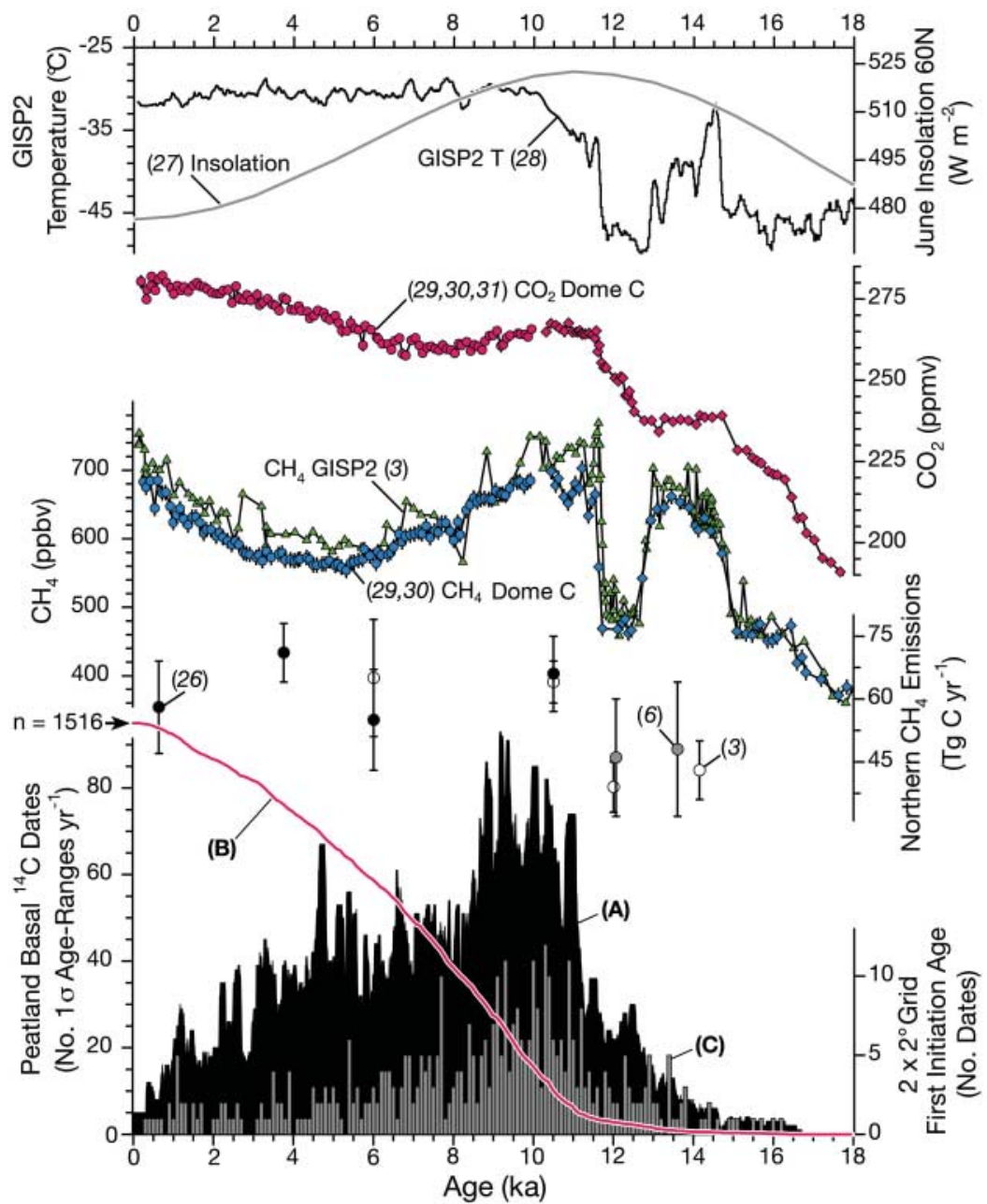

Fig. 3. Timing of circumarctic peatland establishment compared with June insolation at $60^{\circ} \mathrm{N}(26)$, Greenland Ice Sheet Project 2 (GISP2) temperature reconstruction (27), atmospheric $\mathrm{CO}_{2}$ and $\mathrm{CH}_{4}$ concentrations, and estimates of Northern Hemisphere $\mathrm{CH}_{4}$ emissions derived from the InterPolar $\mathrm{CH}_{4}$ Gradient (IPG) $(3,4,6,28)$. Atmospheric $\mathrm{CO}_{2}$ and $\mathrm{CH}_{4}$ concentrations show ice-core data from European Project for Ice Coring in Antarctica (EPICA) Dome $\mathrm{C}$ (red for $\mathrm{CO}_{2}$ and blue for $\mathrm{CH}_{4}$ ) and GISP2 [green triangles show $\mathrm{CH}_{4}(3,29-31)$ ]. Dome $\mathrm{C}$ data are shown on the original EPICA Dome $\mathrm{C} 1$ time scale from 0 to $10 \mathrm{ka}$ before present (circles) and on the GISP2 time scale with $\mathrm{CH}_{4}$ synchronization from 10 to 18 ka before present (diamonds; SOM text). Dome C error bars indicate $1 \sigma$ uncertainty. (A) The occurrence frequency of 1516 radiocarbon dates of basal peat deposits (14) shows the number of calibrated age ranges that occur in any year (black curve). (B) Cumulative curve of 1516 dates (red curve). (C) The oldest basal peat dates within each $2^{\circ}$ by $2^{\circ}$ grid (gray bars).

tral Fennoscandia (19), allowing widespread expansion of peatlands in northern Eurasia (Figs. 1 and 2). A sustained period of maximum rates of peatland establishment followed and persisted until about 8 ka.

The rapid expansion of peatlands at the close of the YD coincides with a $\sim 15-\mathrm{Tg}$ increase in atmospheric $\mathrm{CH}_{4}$ derived from the Northern Hemisphere (Fig. 3) and a 200- to 250-ppbv increase in total $\mathrm{CH}_{4}$ concentrations. According to our data, the northern peatland complex was likely at $<20 \%$ of its current aerial extent at the end of the YD and expanded to about $50 \%$ by $8 \mathrm{ka}$. On the basis of current estimates of overall $\mathrm{CH}_{4}$ production from northern peatlands $(1,2)$, they may have contributed 4 to $9 \mathrm{Tg}$ of Northern Hemisphere $\mathrm{CH}_{4}$ after the end of the YD and up to 12 to $27 \mathrm{Tg}$ by $8 \mathrm{ka}$. However, based on typical peatland succession stages, higher summer insolation in the early Holocene, and evidence of peatland vegetation and type from our peat cores taken in Siberia (7), it is likely that many of these newly developed peatlands were warm and wet minerotrophic fens, often dominated by sedges. Such fens typically emit $\mathrm{CH}_{4}$ at rates many times greater than the ombrotrophic Sphagnum bogs common in much of the north today $(6,20-22)$. Therefore, we suspect that the rates of $\mathrm{CH}_{4}$ production in northern peatlands may have been considerably higher in the early Holocene than they are today

The $\delta^{13} \mathrm{C}_{\mathrm{CH}_{4}}$ values of ice from the Pakitsoq outcrop in western Greenland have been used to infer the likely origins of early-Holocene atmospheric $\mathrm{CH}_{4}$ (11). It has been suggested that major terrestrial sources contributing methane during the period from 11 to 8 ka likely produced $\mathrm{CH}_{4}$ with $\delta^{13} \mathrm{C}$ values of between -50 and -60 (11). Although northern peatlands dominated by ombrogenous bogs may typically emit $\mathrm{CH}_{4}$ with $\delta^{13} \mathrm{C}<-60$, pore waters and emissions of boreal fens are relatively enriched in ${ }^{13} \mathrm{C}$ (average $\delta{ }^{13} \mathrm{C}_{\mathrm{CH}_{4}}$ values of -50 to -60$)$, particularly in high-productivity sites (23). These values are consistent with the early northern peatland complex, dominated by minerotrophic fens, which was a major contributor to the peak in $\mathrm{CH}_{4}$ that occurred 11 to $8 \mathrm{ka}$ and must be considered in addition to the potential tropical sources suggested previously (11).

The rapid growth of the circumarctic peatland complex and its associated sequestration of phytomass carbon in the early Holocene may have also contributed to the decline by $\sim 7$ parts per million by volume (ppmv) of atmospheric $\mathrm{CO}_{2}$ observed in the ice-core records between $11 \mathrm{ka}$ and the mid-Holocene (Fig. 3). This decline has been interpreted as reflecting a total biosphere uptake of $110 \mathrm{Pg} \mathrm{C}$ in the first half of the Holocene (8). More than half of the peatland basal dates in our data set are older than $8 \mathrm{ka}$, indicating rapid initiation and development of this carbon sink in the early Holocene. Conservatively, if by $8 \mathrm{ka}$ peat deposits were 0.5 to $1 \mathrm{~m}$ thick, covered just one-quarter of today's peatland area, and were similar in carbon characteristics to today's northern peatlands (1), they would have been capable of sequestering 29 to $58 \mathrm{Pg} \mathrm{C}$. Further detailed reconstruction of net peat accumulation rates during this period are required to better estimate the magnitude of the contribution of the northern peatlands to early-Holocene atmospheric $\mathrm{CO}_{2}$ declines.

The widespread development of peatlands in response to increasing summer insolation, BA warming, and particularly rapid Holocene warming after the YD supports the hypothesis that the northern peatlands were a major terrestrial factor contributing to the early fluctuations in atmospheric $\mathrm{CH}_{4}$ and to $\mathrm{CO}_{2}$ sequestration during the current interglacial. It is likely that they played a similar role in earlier interglacials. The rapidity and large spatial extent of the response of the northern peatland complex, particularly to the onset of post-YD warming, suggests that they may even have played a role in $\mathrm{CH}_{4}$ and $\mathrm{CO}_{2}$ variations at the shorter time scale of earlier interstadials such as MIS3.

The observed decline in peatland initiation, particularly in Europe and Asia after $8 \mathrm{ka}$, corresponds to a decline in atmospheric $\mathrm{CH}_{4}$ concentrations between 8 and 6 ka (Fig. 3). This decline in initiation rates should not be confused with a decline in total peatland area; most peatlands that were extant at $8 \mathrm{ka}$ were still extant at 6 ka. However, many had trans- 
formed from early minerotrophic fens to ombrotrophic Sphagnum bogs, which are typically weaker sources of $\mathrm{CH}_{4}$ than are fens (20-23). Therefore, the transformation from high $\mathrm{CH}_{4}$ efflux fens to Sphagnum bogs, coupled with a declining rate of new peatland formation, would have contributed to the decline in atmospheric $\mathrm{CH}_{4}$. What remains puzzling is the role that northern peatlands played in the subsequent increase in $\mathrm{CH}_{4}$ between $6 \mathrm{ka}$ and just before the Industrial Revolution. By C.E. 1700, levels of atmospheric $\mathrm{CH}_{4}$ had increased once again to almost 700 ppbv. However, contrary to earlier speculation $(9,15)$, new peatland initiation was relatively modest in the late Holocene, and conversion of fens producing high levels of $\mathrm{CH}_{4}$ to Sphagnum bogs with lower production was ongoing. If the mid- to late-Holocene $\mathrm{CH}_{4}$ increase does not have an anthropogenic explanation, then its source must lie in factors other than large-scale resurgent expansion of the northern peatland complex.

\section{References and Notes}

1. E. Gorham, Ecol. Appl. 1, 182 (1991).

2. S. E. Mikaloff Fletcher, P. P. Tans, L. M. Bruhwiler, ]. B. Miller, M. Heimann, Global Biogeochem. Cycles 18, GB4004, 10.1029/2004GB002223 (2004)

3. E. J. Brook, S. Harder, ]. Severinghaus, E. J. Steig, C. M. Sucher, Global Biogeochem. Cycles 14, 559 (2000).

4. T. Blunier, ]. Chappellaz, ]. Schwander, B. Stauffer, D. Raynaud, Nature 374, 46 (1995).
5. F. Joos, S. Gerber, I. C. Prentice, B. L. Otto-Bliesner, P. ]. Valdes, Global Biogeochem. Cycles 18, 10.1029/3003GB002156 (2004)

6. A. Dällenbach et al., Geophys. Res. Lett. 27, 1005 (2000).

7. L. C. Smith et al., Science 303, 353 (2004)

8. A. Indermühle et al., Nature 398, 121 (1999).

9. J. P. Kennett, K. G. Cannariato, I. L. Hendy, R. J. Behl, Methane Hydrates in Quaternary Climate Change (American Geophysical Union, Washington, DC, 2003).

10. T. Sowers, Science 311, 838 (2006).

11. H. Schaefer et al., Science 313, 1109 (2006).

12. W. F. Ruddiman, Clim. Change 61, 261 (2003).

13. R. Spahni et al., Science 310, 1317 (2005).

14. Radiocarbon dates of basal peat from 1516 selected records from the boreal biome and closely adjacent areas were collated from published articles and reports (table S1). Only basal dates with complete laboratory and geospatial information were included. Radiocarbon ages were calibrated using CALIB 5.0 (24) and the IntCal04 data set (25). In our calculations, the age of peatland initiation is the range of the calibrated age probability distribution at $1 \sigma$ precision rounded to decades. The median span of the calibrated age ranges $(1 \sigma)$ is 300 years. Further details on maps and radiocarbon ages are provided in supporting online material (SOM) text.

15. K. Gajewski, A. Viau, M. Sawada, D. Atkinson, S. Wilson, Global Biogeochem. Cycles 15, 10.1029/2000GB001286 (2001)

16. S.-I. Shin et al., Clim. Dyn. 20, 127 (2003)

17. A. S. Dyke, A. Moore, L. Robertson, Deglaciation of North America (Geological Survey of Canada Open File 1574, Ottawa, Canada, 2003).

18. L. Gualtieri, S. L. Vartanyan, ]. Brigham-Grette, P. M. Anderson, Boreas 34, 264 (2005).

19. J. Donner, The Quaternary History of Scandinavia (Cambridge Univ. Press, Cambridge, UK, 1995).
20. H. Almquist-Jacobson, D. R. Foster, Ecology 76, 2503 (1995)

21. K. B. Bartlett, R. C. Harriss, Chemosphere 26, 261 (1993).

22. T. Christensen et al., Geophys. Res. Lett. 30, 10.1029/2002GL016848 (2003).

23. L. M. Bellisario, ]. L. Bubier, T. L. Moore, J. P. Chanton, Global Biogeochem. Cycles 13, 81 (1999).

24. M. Stuiver, P. J. Reimer, Radiocarbon 35, 215 (1993).

25. P. J. Reimer et al., Radiocarbon 46, 1029 (2004).

26. J. Chappellaz et al., J. Geophys. Res. 102, 15987 (1997)

27. A. Berger, M. F. Loutre, Quat. Sci. Rev. 10, 297 (1991).

28. R. B. Alley, Quat. Sci. Rev. 19, 213 (2000).

29. ]. Flückiger et al., Global Biogeochem. Cycles 16, 1010, 10.1029/2001GB001417 (2002).

30. E. Monnin et al., Science 291, 112 (2001).

31. E. Monnin et al., Earth Planet. Sci. Lett. 224, 45 (2004).

32. Research funding was provided by NSF through the Arctic System Science Program (ARCSS) through the RussianAmerican Initiative on Shelf-Land Environments of the Arctic (grant OPP-9818496) and a Doctoral Dissertation Research Improvement Grant from the Geography Program (grant SRB-0425625). We thank our many colleagues from the United States, Russia, Canada, and Finland for helpful discussions on our results and assistance in compiling radiocarbon dates. We thank ]. Flückiger for providing helpful comments on an earlier draft and for important comparative data.

\section{Supporting Online Material}

www.sciencemag.org/cgi/content/full/314/5797/285/DC1 SOM Text

Table S1

References

26 June 2006; accepted 5 September 2006 $10.1126 /$ science.1131722

\section{Gold in Magmatic Hydrothermal Solutions and the Rapid Formation of a Giant Ore Deposit}

\section{Stuart F. Simmons ${ }^{1 *}$ and Kevin L. Brown ${ }^{2}$}

The Ladolam hydrothermal system, on Lihir Island, Papua New Guinea, hosts one of the youngest and largest gold deposits in the world. Several deep (more than 1 kilometer) geothermal wells were drilled beneath the ore bodies to extract water at $>275^{\circ} \mathrm{C}$ and to facilitate open-pit mining. Using a titanium down-hole sampler, we determined that the deep geothermal brine of magmatic origin contains $\sim 15$ parts per billion gold. At the current gold flux of 24 kilograms per year, this deposit could have formed within $\sim 55,000$ years. The combination of sustained metal flux and efficient metal precipitation led to the formation of a giant hydrothermal gold deposit in a short period.

$\mathrm{T}$ he origins of giant hydrothermal gold deposits are enigmatic (1). This is because the concentrations of precious metals and flow rates of ore-forming fluids are poorly quantified, and the origins of the metals are unclear. These aspects can be clarified with direct analyses of fluids from modern hydrothermal systems. The only known active hydrothermal gold deposit is at Ladolam, on

${ }^{1}$ Geology Dept., Univ. of Auckland, Private Bag 92019, Auckland Mail Centre, Auckland 1142, New Zealand. ${ }^{2}$ GEOKEM, P. O. Box 95-210, Swanson, Waitakere 0653, New Zealand.

*To whom correspondence should be addressed. E-mail: sf.simmons@auckland.ac.nz
Lihir Island, Papua New Guinea, and this deposit is one of the largest in the world with $\sim 1300$ tons of gold. Geothermal drilling at Ladolam has been ongoing since before the start of open-pit mining in 1997, and the wells provide access to the deep fluids upstream of the ore zone. Because precious metals precipitate in the wells during fluid ascent due to boiling (2), we used a titanium down-hole sampler to obtain deep fluids for analyses (3). Any metals that precipitate in the sampler during its return to the surface can be incorporated into the water sample by rinsing the titanium sampler with strong acid. Thus, the deep metal concentrations can be directly measured and used to constrain the rate at which the gold is transported and then deposited in order to form this giant deposit. Because the isotopic compositions of the deep hydrothermal waters at Ladolam are predominantly magmatic in origin (4), our data cover not just the origin of the metals, but also the concentrations of gold and related metals in magmatic hydrothermal solutions, which are thought to be important to the formation of ore deposits $(5,6)$.

The Ladolam gold deposit occupies the center of the extinct Luise volcano on Lihir Island (Fig. 1). The two major tabular ore zones cover $\sim 2 \mathrm{~km}^{2}$ and extend from the surface to $400 \mathrm{~m}$ below sea level. They lie in the middle of a breached crater that formed in response to sector collapse and unroofing of the volcanic edifice $\sim 400,000$ years ago $(4,7,8)$. The resulting explosive depressurization of the magmatic-hydrothermal system produced a diatreme breccia complex and highly permeable rocks, which now host the ore. Mineralogical, fluid inclusion, and isotope studies (4) show that the gold was deposited in two stages between $150^{\circ}$ and $250^{\circ} \mathrm{C}$, from solutions of magmatic origin, when they mixed with other fluids or boiled. The magmatic gold-bearing solutions were near neutral to slightly alkaline $\mathrm{pH}$ and contained 5 to 10 wt $\%$ equivalent $\mathrm{NaCl}$. The host rocks comprise alkalic mafic to intermediate volcanic and intrusive rocks (9) that have been hydro- 


\section{Science \\ MIAAAS}

\section{A Combined Mitigation/Geoengineering Approach to} Climate Stabilization

T. M. L. Wigley, et al.

Science 314, 452 (2006);

DOI: $10.1126 /$ science. 1131728

\section{The following resources related to this article are available online at www.sciencemag.org (this information is current as of January 30, 2007 ):}

Updated information and services, including high-resolution figures, can be found in the online version of this article at:

http://www.sciencemag.org/cgi/content/full/314/5798/452

A list of selected additional articles on the Science Web sites related to this article can be found at:

http://www.sciencemag.org/cgi/content/full/314/5798/452\#related-content

This article cites 9 articles, 2 of which can be accessed for free:

http://www.sciencemag.org/cgi/content/full/314/5798/452\#otherarticles

This article appears in the following subject collections:

Atmospheric Science

http://www.sciencemag.org/cgi/collection/atmos

Information about obtaining reprints of this article or about obtaining permission to reproduce

this article in whole or in part can be found at:

http://www.sciencemag.org/help/about/permissions.dtl 
ments into the marsh. Because hurricanes are so important to the inorganic sediment budget, other factors must be considered to understand how to reduce wetland losses and further their restoration. Changes in the in situ accumulation of organics, rather than the reduction of inorganic sediments arriving via overbank flooding, are implicated as a causal agent of wetland losses on this coast. This is illustrated by the fact that the soil volume occupied by organic sediments plus water in healthy saltmarsh wetlands is $>90 \%$ (10) and is certainly the same or higher in wetlands of lower salinity. This organic portion plays a major role in wetland soil stability and hence in wetland ecosystem health (19).

\section{References and Notes}

1. R. H. Baumann, R. E. Turner, Environ. Geol. Water Res. 15, 189 (1990).

2. T. A. Morton, J. C. Bernier, J. A. Barras, N. F. Ferina, USGS Open-File Rep. 2005-1215 (2005).

3. G. W. Stone, X. Zhang, A. Sheremet, J. Coastal Res. 44, 40 (2005).

4. J. M. Rybczyk, D. R. Cahoon, Estuaries 25, 985 (2002).

5. M. L. Parsons, J. Coastal Res. 14, 939 (1998).

6. D. R. Cahoon et al., J. Coastal Res. 21 (special issue), 280 (1995).

7. J. P. Morgan, L. G. Nichols, M. Wright, Morphological Effect of Hurricane Audrey on the Louisiana Coast (contribution no. 58-3, Coastal Studies Institute, Louisiana State Univ., Baton Rouge, LA, 1958).

8. J. A. Nyman, R. D. DeLaune, H. H. Roberts, W. H. Patrick Jr., Mar. Ecol. Prog. Ser. 96, 269 (1992).

9. Materials and methods are available as supporting material on Science Online.

10. R. E. Turner, E. M. Swenson, C. S. Milan, in Concepts and Controversies in Tidal Marsh Ecology, M. Weinstein, D. A. Kreeger, Eds. (Kluwer, Dordrecht, Netherlands, 2001), pp. 583-595.

11. The peak water measured by U.S. Geological Survey water-level gage 30174809020900, at Pass Manchac Turtle Cove near Ponchatoula, LA, in the western Lake Pontchartrain watershed, was about $6 \mathrm{~cm}$ higher during Hurricane Rita than during Hurricane Katrina, even though the hurricane path was over $300 \mathrm{~km}$ further away.

12. Storm surge model results for Hurricanes Katrina and Rita are available at the Louisiana State University Hurricane Center Web sites (http://hurricane.Isu.edu/floodprediction/ katrina/deadly funnel1.jpg and http://hurricane.lsu.edu/ floodprediction/rita24/images/adv24_SurgeTX_LA.jpg).

13. G. J. Chakrapani, Curr. Sci. 88, 569 (2005).

14. R. H. Baumann, thesis, Louisiana State Univ., Baton Rouge, LA (1980).

15. D. J. Reed, N. De Luca, A. L. Foote, Estuaries 20, 301 (1997).

16. G. A. Snedden, J. E. Cable, C. Swarzenski, E. Swenson, Estuar. Coastal Shelf Sci., in press.

17. R. E. Turner, Estuaries 14, 139 (1991).

18. K. W. Wheelock, thesis, Louisiana State Univ., Baton Rouge, LA (2003).

19. R. E. Turner, E. M. Swenson, C. S. Milan, J. M. Lee, T. A. Oswald, Ecol. Res. 19, 29 (2004).
20. R. H. Kesel, Environ. Geol. Water Res. 11, 271 (1988)

21. C. M. Belt Jr., Science 189, 681 (1975).

22. Kesel (20) estimated the sediment load in the spring floods using water records from 1950 to 1983 and determined the amount of sediment that would be available from unconfined overbank flooding if the levees were not there. The estimate is actually an overestimate of the amount available, because the artificial constriction of the river channel throughout the basin raised the flood stage for the same-sized discharge event (21).

23. Supported by the NSF Division of Geomorphology and Land-Use Dynamics (award EAR-061250), the National Oceanic and Atmospheric Administration Coastal Ocean Program MULTISTRESS (award no. NA160P2670), and a Louisiana Board of Regents Fellowship (].S.S.). We thank J. Gore for assistance in sampling from an airboat; E. Babin for assistance in finding photographs; H. Hampp, our deft, safe, and considerate helicopter pilot; and B. Sen Gupta, N. N. Rabalais, and three anonymous reviewers for constructive reviews of the manuscript.

\section{Supporting Online Material}

www.sciencemag.org/cgi/content/full/1129116/DC1

Materials and Methods

SOM Text

Fig. S1

Table S1

References and Notes

24 April 2006; accepted 1 September 2006

Published online 21 September 2006;

10.1126/science.1129116

Include this information when citing this paper.

\section{A Combined Mitigation/Geoengineering Approach to Climate Stabilization}

\section{T. M. L. Wigley}

Projected anthropogenic warming and increases in $\mathrm{CO}_{2}$ concentration present a twofold threat, both from climate changes and from $\mathrm{CO}_{2}$ directly through increasing the acidity of the oceans. Future climate change may be reduced through mitigation (reductions in greenhouse gas emissions) or through geoengineering. Most geoengineering approaches, however, do not address the problem of increasing ocean acidity. A combined mitigation/geoengineering strategy could remove this deficiency. Here we consider the deliberate injection of sulfate aerosol precursors into the stratosphere. This action could substantially offset future warming and provide additional time to reduce human dependence on fossil fuels and stabilize $\mathrm{CO}_{2}$ concentrations cost-effectively at an acceptable level.

$\mathrm{I}$ $\mathrm{n}$ the absence of policies to reduce the magnitude of future climate change, the globe is expected to warm by $\sim 1^{\circ}$ to $6^{\circ} \mathrm{C}$ over the 21 st century $(1,2)$. Estimated $\mathrm{CO}_{2}$ concentrations in 2100 lie in the range from 540 to 970 parts per million, which is sufficient to cause substantial increases in ocean acidity (3-6). Mitigation directed toward stabilizing $\mathrm{CO}_{2}$ concentrations (7) addresses both problems but presents considerable economic and technological challenges $(8,9)$. Geoengineering $(10-17)$ could help reduce the future extent of climate change due to warming but does not address the problem of ocean acidity. Mitigation is therefore necessary, but geoengineering could provide additional time to address the economic and

National Center for Atmospheric Research, Post Office Box 3000, Boulder, CO 80307-3000, USA. E-mail: wigley@ ucar.edu

technological challenges faced by a mitigationonly approach.

The geoengineering strategy examined here is the injection of aerosol or aerosol precursors [such as sulfur dioxide $\left(\mathrm{SO}_{2}\right)$ ] into the stratosphere to provide a negative forcing of the climate system and consequently offset part of the positive forcing due to increasing greenhouse gas concentrations (18). Volcanic eruptions provide ideal experiments that can be used to assess the effects of large anthropogenic emissions of $\mathrm{SO}_{2}$ on stratospheric aerosols and climate. We know, for example, that the Mount Pinatubo eruption [June $1991(19,20)]$ caused detectable short-term cooling (19-21) but did not seriously disrupt the climate system. Deliberately adding aerosols or aerosol precursors to the stratosphere, so that the loading is similar to the maximum loading from the Mount Pinatubo eruption, should therefore present minimal climate risks.
Increased sulfate aerosol loading of the stratosphere may present other risks, such as through its influence on stratospheric ozone. This particular risk, however, is likely to be small. The effect of sulfate aerosols depends on the chlorine loading (22-24). With current elevated chlorine loadings, ozone loss would be enhanced. This result would delay the recovery of stratospheric ozone slightly but only until anthropogenic chlorine loadings returned to levels of the 1980s (which are expected to be reached by the late 2040s).

Figure 1 shows the projected effect of multiple sequential eruptions of Mount Pinatubo every year, every 2 years, and every 4 years. The Pinatubo eruption-associated forcing that was used had a peak annual mean value of $-2.97 \mathrm{~W} / \mathrm{m}^{2}(20,21)$. The climate simulations were carried out using an upwelling-diffusion energy balance model [Model for the Assessment of Greenhouse gas-Induced Climate Change (MAGICC) $(2,25,26)]$ with a chosen climate sensitivity of $3^{\circ} \mathrm{C}$ equilibrium warming for a $\mathrm{CO}_{2}$ doubling $\left(2 \times \mathrm{CO}_{2}\right)$. Figure 1 suggests that a sustained stratospheric forcing of $\sim-3 \mathrm{~W} / \mathrm{m}^{2}$ (the average asymptotic forcing for the biennial eruption case) would be sufficient to offset much of the anthropogenic warming expected over the next century. Figure 1 also shows how rapidly the aerosol-induced cooling disappears once the injection of material into the stratosphere stops, as might become necessary should unexpected environmental damages arise.

Three cases are considered to illustrate possible options for the timing and duration of aerosol injections. In each case, the loading of the stratosphere begins in 2010 and increases linearly to 
$-3 \mathrm{~W} / \mathrm{m}^{2}$ over 30 years. The options depart from each other after this date (Fig. 2). These geoengineering options are complemented by three future $\mathrm{CO}_{2}$ emissions scenarios: a central "no climate policy" scenario from the Special Report on Emissions Scenarios (SRES) (27) data set, namely the A1B scenario; an ambitious scenario known as WRE450 (7) in which $\mathrm{CO}_{2}$ concentration stabilizes at $450 \mathrm{ppm}$ (the present level is $\sim 380 \mathrm{ppm}$ ); and an overshoot scenario in which $\mathrm{CO}_{2}$ concentration rises to $530 \mathrm{ppm}$ in 2080 before declining to $450 \mathrm{ppm}$. [Because an atmospheric $\mathrm{CO}_{2}$ concentration of $450 \mathrm{ppm}$ "produces both calcite and aragonite undersaturation in most of the deep ocean" (4), a level even less than this may ultimately be desirable.]

$\mathrm{CO}_{2}$ concentrations and corresponding fossil fuel emissions for these three $\mathrm{CO}_{2}$ scenarios are shown in Fig. 3. Emissions for the stabilization cases were calculated with the use of an inverse version of MAGICC, which accounted for climate feedbacks on the carbon cycle. The WRE450 scenario is an archetypal mitigation-only case, stabilizing at a level that many researchers believe would avoid "dangerous anthropogenic interference" with the climate system (28). The overshoot scenario is introduced here to be considered in conjunction with the three geoengineering options. It allows much larger $\mathrm{CO}_{2}$ emissions and a much slower departure from the A1B no-policy scenario baseline. Although the rate of decline of emissions in the mid- to late 21 st century is more rapid in the overshoot scenario than in WRE450, these reductions begin 15 to 20 years later in the former scenario, allowing additional time both to phase out existing $\mathrm{CO}_{2}$-emitting fossil fuel energy technologies and to develop and deploy energy sources that have net-zero $\mathrm{CO}_{2}$ emissions (7-9).

Figure 4 shows global mean temperature and sea-level projections for the no-policy scenario (A1B), the mitigation-only scenario (WRE450), and the overshoot $\mathrm{CO}_{2}$ scenario combined with the three alternative geoengineering options (HIGH GEO, MID GEO, and LOW GEO). For the decades immediately after 2010 , changes in aerosol forcing in all three GEO options occur more rapidly than forcing changes for the $\mathrm{CO}_{2}$ scenarios, so the net effect is cooling. After 2040, the HIGH GEO-associated cooling tends to balance the warming from the overshoot $\mathrm{CO}_{2}$ stabilization scenario, eventually leading to a slight cooling that would bring global mean temperatures back to near their preindustrial level. The MID and LOW GEO options lead to temperatures stabilizing at approximately $1^{\circ}$ and $2^{\circ} \mathrm{C}$ relative to temperatures in 2000 (29). After 2100, the LOW GEO option (where injection into the stratosphere is decreased to zero by 2090) closely matches the WRE450 mitigation-only scenario but requires less-stringent emissions reductions.

The sea-level results (Fig. 4B), derived from models used in the Third Assessment Report

Fig. 1. (left) Global mean temperature response to multiple volcanic eruptions. The standard eruption used was that of Mount Pinatubo [forcing data from Ammann et al. $(20,21)]$, and eruptions were assumed to occur every 4 years (top curve), every 2 years (middle curve), or every year (bottom curve). The results shown are annual mean values
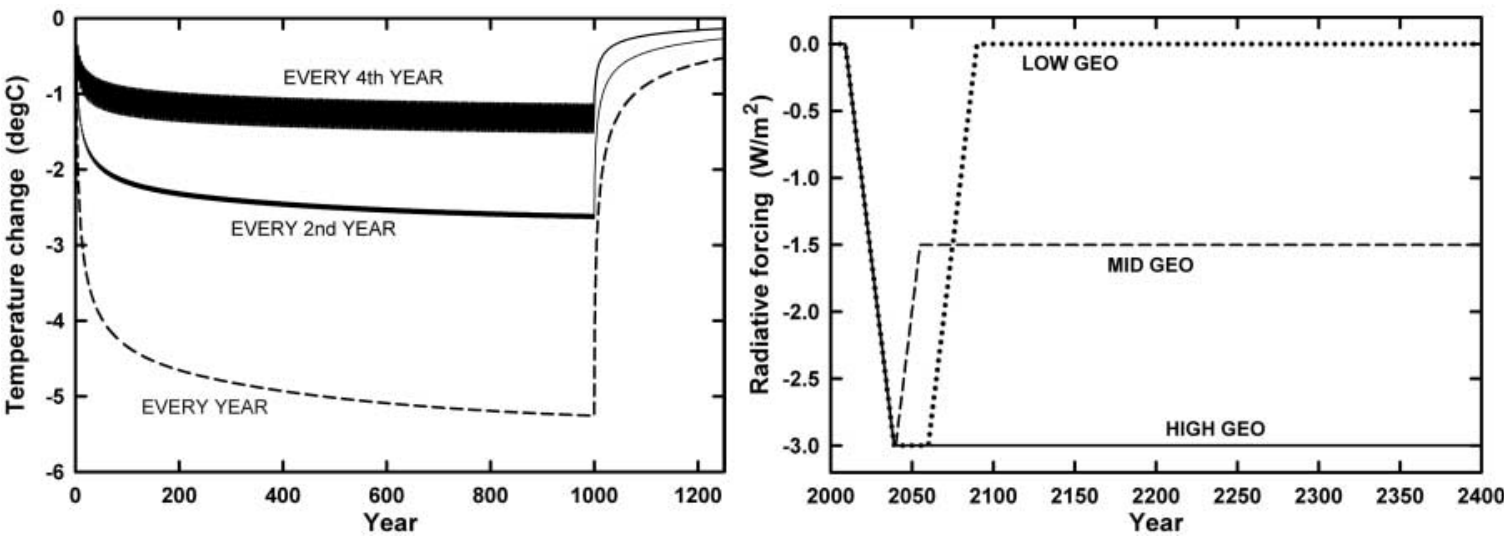
plotted year by year. In the 2- and (especially) 4-year cases, the forcing varies considerably from year to year, leading to noticeable interannual temperature variations. These appear as bands of values because the abscissa scale in the graph is insufficient to resolve these rapid variations. A climate sensitivity of $3^{\circ} \mathrm{C}$

equilibrium warming for $2 \times \mathrm{CO}_{2}$ is assumed. forcing scenarios for the three geoengineering options considered. The HIGH GEO option corresponds approximately to the steady-state forcing that would result from eruptions of Mount Pinatubo every 2 years.
Fig. 3. (left) (A) $\mathrm{CO}_{2}$ concentration projections used in the analysis together with (B) corresponding fossil fuel emissions. The overshoot scenario was used in conjunction with the three geoengineering options shown in Fig. 2. A climate sensitivity of $3^{\circ} \mathrm{C}$ equilibrium warming for $2 \times$ $\mathrm{CO}_{2}$ is assumed. $\mathrm{CO}_{2}$ emissions results depend on the climate sensitivity because of climate feedbacks on the carbon cycle. GtC, gigatons of carbon. Fig. 4. (right) Global mean temperature (A) and sea-level (B) changes for the A1B scenario, the WRE450 scenario, and three scenarios combining both mitigation and geoengineering. The latter cases use the overshoot scenario (Fig. 3) and the three increasingly strong geoengineering options (Fig. 2). A climate sensitivity of $3^{\circ} \mathrm{C}$ equilibrium warming for $2 \times \mathrm{CO}_{2}$ is assumed.
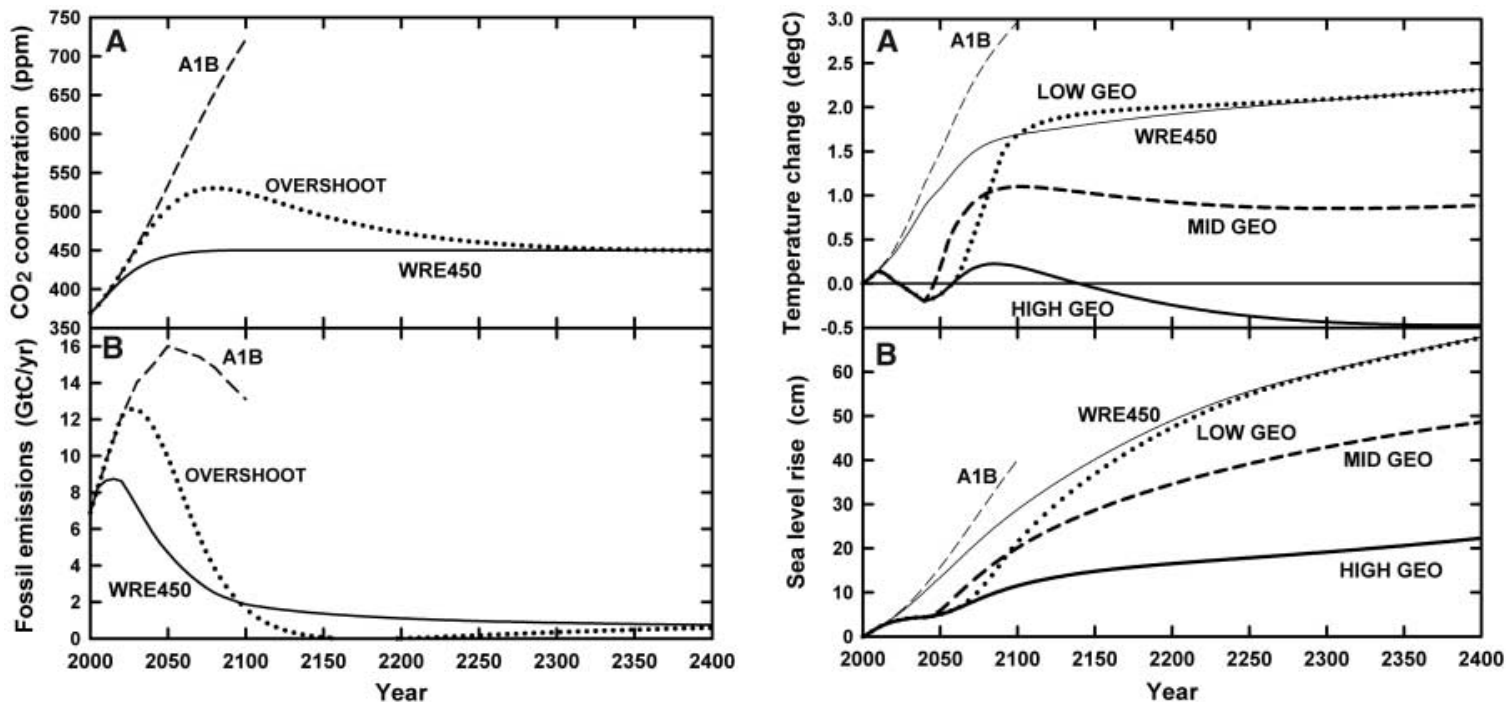
of the Intergovernmental Panel on Climate Change $(30,31)$, show the much larger inertia of this part of the climate system. The LOW GEO option and WRE450 scenario again are similar, with neither tending toward stabilization. Even the HIGH GEO option shows a continuing (but slow) rise in sea level toward the end of the study period, but the rate of rise is small, even relative to changes observed over the 20th century $(30,32)$.

A combined mitigation/geoengineering approach to climate stabilization has a number of advantages over either alternative used separately. A relatively modest geoengineering investment $(33,34)$ corresponding to the present LOW GEO option could reduce the economic and technological burden on mitigation substantially, by deferring the need for immediate or near-future cuts in $\mathrm{CO}_{2}$ emissions. More ambitious geoengineering, when combined with mitigation, could even lead to the stabilization of global mean temperature at near present levels and reduce future sea-level rise to a rate much less than that observed over the 20th century: aspects of future change that are virtually impossible to achieve through mitigation alone.

As a guide to the amount of $\mathrm{SO}_{2}$ required, the eruption of Mount Pinatubo injected about 10 teragrams of sulfur ( $\mathrm{TgS}$ ) into the stratosphere $(35,36)$, and the analysis here suggests that an annual flux of half that amount would have a substantial influence. Smaller diameter aerosols would have longer lifetimes and require still smaller injection rates (15). Five TgS/year is only $\sim 7 \%$ of current $\mathrm{SO}_{2}$ emissions from fossil fuel combustion $(37,38)$. Further analysis is required to assess (i) the technological feasibility of the suggested injections of $\mathrm{SO}_{2}$ [or of more radiatively efficient material (34)] into the stratosphere, (ii) the economic costs of this option relative to the reduced costs of mitigation that an overshoot $\mathrm{CO}_{2}$-stabilization pathway would allow, and (iii) the detailed effects of the proposed $\mathrm{SO}_{2}$ injections and $\mathrm{CO}_{2}$ concentration changes on climate [compare with (39)] and stratospheric chemistry.

\section{References and Notes}

1. U. Cubasch, G. A. Meehl, in Climate Change 2001: The Scientific Basis, J. T. Houghton et al., Eds. (Cambridge Univ. Press, Cambridge, 2001), pp. 525-582.

2. T. M. L. Wigley, S. C. B. Raper, Science 293, 451 (2001).

3. K. Caldeira, M. E. Wickett, Nature 425, 365 (2003).

4. K. Caldeira, M. E. Wickett, J. Geophys. Res. $\mathbf{1 1 0}$ 10.1029/2004]C002671 (2005).

5. J. C. Orr et al., Nature 437, 681 (2005).

6. A. J. Andersson, F. T. Mackenzie, A. Lerman, Global Biogeochem. Cycles 20, 10.1029/2005GB002506 (2006).

7. T. M. L. Wigley, R. Richels, J. A. Edmonds, Nature 379, 240 (1996).

8. M. I. Hoffert et al., Nature 395, 881 (1998)

9. M. I. Hoffert et al., Science 298, 981 (2002).

10. Geoengineering refers to engineering aimed at counteracting the undesired side effects of other human activities (11). Two classes may be distinguished: climate engineering (12-15) and carbon cycle engineering [for example, through modifying ocean alkalinity $(16,17)]$. Here, the word geoengineering refers specifically to climate engineering (i.e., direct and intentional management of the climate system).
11. D. W. Keith, Annu. Rev. Energy Environ. 25, 245 (2000).

12. S. H. Schneider, Nature 409, 417 (2001).

13. National Academy of Sciences, Policy Implications of Greenhouse Warming: Mitigation, Adaptation and the Science Base (National Academy Press, Washington, DC 1992), pp. 433-464.

14. B. P. Flannery et al., in Engineering Response to Global Climate Change: Planning a Research and Development Agenda, R. G. Watts, Ed. (Lewis Publishers, Boca Raton, FL, 1997), pp. 379-427.

15. P. J. Crutzen, Clim. Change 76, 10.1007/s10584-006-9101-y (2006).

16. H. S. Kheshgi, Energy 20, 915 (1995).

17. K. S. Lackner, Annu. Rev. Energy Environ. 27, 193 (2002).

18. M. I. Budyko, Climate Changes (Engl. transl.) (American Geophysical Union, Washington, DC, 1977).

19. A. Robock, Rev. Geophys. 38, 191 (2000).

20. C. M. Ammann, G. A. Meehl, W. M. Washington, C. S. Zender, Geophys. Res. Lett. 30, 10.1029/2003GL016875 (2003).

21. T. M. L. Wigley, C. M. Ammann, B. D. Santer, S. C. B. Raper, J. Geophys. Res. 110, 10.1020/2004JD005557 (2005).

22. X. Tie, G. Brasseur, Geophys. Res. Lett. 22, 3035 (1995).

23. S. Solomon et al., J. Geophys. Res. 101, 6713 (1996).

24. R. W. Portmann et al., J. Geophys. Res. 101, 22991 (1996).

25. MAGICC is a suitable tool because it reproduces the results from more complex coupled ocean/atmosphere general circulation models for both volcanic time-scale (21) and long-term (26) forcing.

26. S. C. B. Raper, ]. M. Gregory, T. J. Osborn, Clim. Dyn. 17, 601 (2001)

27. N. Nakićenović, R. Swart, Eds., Special Report on Emissions Scenarios (Cambridge Univ. Press, Cambridge, 2000).

28. Avoiding dangerous anthropogenic interference with the climate system is one of the primary guidelines for climate policy espoused in Article 2 of the United Nations Framework Convention on Climate Change.

29. In all options, there is a residual warming tendency arising from the emissions of non- $\mathrm{CO}_{2}$ gases (such as $\mathrm{CH}_{4}, \mathrm{~N}_{2} \mathrm{O}$, halocarbons, and tropospheric aerosols). Emissions from these sources are assumed to follow the
A1B scenario to 2100 and then remain constant, leading to a slow but long-term increase in radiative forcing.

30. J. A. Church, J. M. Gregory, in Climate Change 2001: The Scientific Basis, ]. T. Houghton et al., Eds. (Cambridge Univ. Press, Cambridge, 2001), pp. 639-694.

31. T. M. L. Wigley, S. C. B. Raper, Geophys. Res. Lett. 32, 10.1029/2004GL021238 (2005).

32. A. Cazenave, R. S. Nerem, Rev. Geophys. 42, 10.1029/2003RG000139 (2004).

33. Teller et al. (34) point out that sulfate aerosols are "grossly nonoptimized" as scatterers of short-wave radiation and that metallic or resonant scatterers offer large mass savings. Although emplacement costs for such scatterers would be higher, they estimate net costs (for metals) to be "as much as five times less" than for sulfate aerosols.

34. E. Teller, R. Hyde, L. Wood, Active Climate Stabilization: Practical Physics-Based Approaches to Prevention of Climate Change (Preprint UCRL-JC-148012, Lawrence Livermore National Laboratory, Livermore, CA, 2002); www.llnl.gov/global-warm/148012.pdf.

35. G. J. S. Bluth, S. D. Doiron, C. C. Schnetzler, A. J. Krueger, L. S. Walter, Geophys. Res. Lett. 19, 151 (1992).

36. S. Guo, G. J. S. Bluth, W. I. Rose, I. M. Watson, A. ]. Prata, Geochem. Geophys. Geosys. 5, 10.1029/2003GC000654 (2004)

37. S. J. Smith, H. Pitcher, T. M. L. Wigley, Global Planet. Change 29, 99 (2001)

38. At steady-state conditions, an injection of $5 \mathrm{TgS} /$ year into the stratosphere would increase the flux into the troposphere by the same amount, with larger fluxes in high latitudes. Given current emissions, the consequences of this extra flux are likely to be minor, but this aspect warrants further attention.

39. B. Govindasamy, K. Caldeira, Geophys. Res. Lett. 17 2151 (2000)

40. The National Center for Atmospheric Research is supported by NSF.

26 June 2006; accepted 6 September 2006 Published online 14 September 2006;

10.1126/science.1131728

Include this information when citing this paper.

\section{Dendritic Cell Stimulation by Mycobacterial Hsp70 Is Mediated Through CCR5}

R. Andres Floto, ${ }^{1 *}$ Paul A. MacAry, ${ }^{1,2 *}$ Jessica M. Boname, ${ }^{1}$ Tan Suet Mien, ${ }^{3}$ Beate Kampmann, ${ }^{4}$ James R. Hair, ${ }^{1}$ Oh Seen Huey, ${ }^{2}$ Edith N. G. Houben, ${ }^{5}$ Jean Pieters, ${ }^{5}$ Cheryl Day, ${ }^{6}$ Wulf Oehlmann, ${ }^{7}$ Mahavir Singh, ${ }^{7}$ Kenneth G. C. Smith, ${ }^{1}$ Paul ]. Lehner ${ }^{1} \dagger$

An effective host immune response to mycobacterial infection must control pathogen dissemination without inducing immunopathology. Constitutive overexpression of mycobacterial heat shock protein (myHsp70) is associated with impaired bacterial persistence, but the immune-mediated mechanisms are unknown. We found that myHsp70, in addition to enhancing antigen delivery to human dendritic cells, signaled through the CCR5 chemokine receptor, promoting dendritic cell aggregation, immune synapse formation between dendritic cells and T cells, and the generation of effector immune responses. Thus, CCR5 acts as a pattern-recognition receptor for myHsp70, which may have implications for both the pathophysiology of tuberculosis and the use of myHsps in tumor-directed immunotherapy.

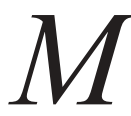
ycobacterium tuberculosis infects one-third of the world's population and is responsible for two million deaths annually. A tightly controlled $\mathrm{T}$ cell response to M. tuberculosis results in granuloma formation, which limits mycobacterial replication and controls the immunopathological conse- quences of infection (1). The immune response and granuloma formation are regulated by host and mycobacterial factors (2); one of these, mycobacterial heat shock protein 70 (myHsp70), stimulates dendritic cells (DCs) to release proinflammatory mediators (3). Hsps are conserved between microorganisms and mammalian cells 